Egyptian Journal of Aquatic Biology \& Fisheries

Zoology Department, Faculty of Science,

Ain Shams University, Cairo, Egypt.

ISSN $1110-6131$

Vol. 24(5): 483 - 509 (2020)

www.ejabf.journals.ekb.eg

\title{
Effect of climate change on growth and reproduction of Nile tilapia (Oreochromis niloticus, L.) from Bahr Shebeen Canal, Delta of Egypt.
}

\author{
Elsayed A. Khallaf *, A.A. Alne-na-ei, F. A. El-messady, and Esraa Hanafy \\ Zoology department, Faculty of Science, Menoufia university, Shebeen alkoom,Egypt.
}

*Corresponding Author:ekhallaf@yahoo.com

\section{ARTICLE INFO}

\section{Article History:}

Received: July 25, 2020

Accepted: Aug. 17, 2020

Online: Aug. 20, 2020

Keywords:

Global warming,

Growth,

Reproduction,

Oreochromis niloticus,

Bahr Shebeen.

\begin{abstract}
Global warming was noticed in the last five years, and its effects on various biological processes of animals are imminent. Therefore, this study was carried out to examine such effects on the growth and reproduction of Oreochromis niloticus, from Bahr Shebeen Canal. Growth in length of fish was significant, where $\mathrm{r}^{2}$ was 0.93 and 0.97 for males and females, respectively. The weightlength relationship exponent was found to be 2.5842 and 2.7994 for males and females, respectively. The samples under study were found to fall into 5 agegroups. The condition coefficient showed a seasonal decrease in going from winter to spring for both sexes. The sex ratio for males and females $O$. niloticus was found to be 1:0.53. GSI values for both sexes indicated that sexual maturity is achieved at a smaller length and younger ages in females than males. Seasonal variations of GSI values indicated multiple spawning. Fecundity showed a gradual decrease in going from winter to autumn. It was also noticed that it decreased with the excessively high temperatures of the summer months. Those predictions were discussed and compared to previous studies, which could be related to the prevalent warmer weather.
\end{abstract}

\section{INTRODUCTION}

Global warming showed an increase of $0.6^{\circ} \mathrm{C}$ in the last century, this is unprecedented in the last 1000 years. The Intergovernmental Panel on Climate Change (IPCC, 2001) predicted that global temperatures are likely to be increased by 1.4 to $6.4^{\circ} \mathrm{C}$ in this century. Air temperature is the main controller governing water temperature in rivers and oceans. Temperature is an effective environmental factor for the biology of different animals. For fishes, being poikilothermic organisms, they are affected by the ambient temperature of the water (Britz et al., 1997; Azevedo et al., 1998). 
Tilapias are considered as the basis of fishing, because they represent more than $70 \%$ of the Egyptian landing. They are the main species inhabiting the River Nile and irrigation canals network in Egypt (Ishak et al., 1985; AL-Zahaby et al., 1987).

Nile tilapia (Oreochromis niloticus) represents the basis of commercial fisheries in a lot of African countries in tropical and subtropical freshwater (Mohammed and Uraguchi, 2013). O. niloticus can live longer than 10 years and achieve weights of $5 \mathrm{~kg}$ (FAO, 2020). Studying Growth and age structures is vital for understanding of ecology and the population dynamics of fishes (Chilton and Beamish, 1982;). It was emphasized by Khallaf and Alne-na-ei (1987) the extent of correlation of $O$. niloticus biological processes with temperature and photoperiod. Accordingly, this study was suggested because of the sensitivity of such species to change in climate.

\section{MATERIALS AND METHODS}

\section{Study area:}

Bahr Shebeen Canal (BSC) is a semi-independent water ecosystem throughout three governorates in the Egyptian delta (Khallaf and Alne-na-ei, 1987; Khallaf and Authman, 1991; Khallaf and Authman, 1992).

\section{Collection of samples:}

A total of 360 adult Oreochromis niloticus specimens: 236 males and 124 females were caught by trammel nets, at different localities of Bahr Shebeen Canal, during consecutive months between February 2018 to January 2019. The collected samples were immediately brought to the laboratory at Faculty of Science, Menoufia University and the following observations were recorded: Date of capture, number of sample, morphometric parameters such as total and standard lengths were then measured using a ruler to the nearest centimeter, and body weight was measured to the nearest gram.

Temperature measurements were supplied by the monthly records from Https://www.accuweather .com

About 15-20 fish scales were carefully removed from the left side of each fish between the dorsal fin and lateral line from the region below the pectoral fin (Rounsefell and Everhart, 1953), and kept in labeled envelopes for later examination.

\section{Growth:}

\section{1-Length-weight relationship:}

The regression of this relationship was computed as indicated by Le Cren (1951). $\mathrm{W}=\mathrm{a} \mathrm{L}^{\mathrm{b}}$

Where: $\mathrm{W}=$ fish weight in grams, $\mathrm{L}=$ fish standard length in centimeters and regression constants are $\mathrm{a}$ and $\mathrm{b}$.

\section{2-Age determination:}

The scales were kept in $10 \%$ solution of ammonium hydroxide for one day to be cleaned, then washed by distilled water, dried using filter paper and mounted between two glass 
slides. Age annuli were identified by examination of each fish scale using a light microscope at 10x magnification accorging to 1956).

Condition factor (coefficient):

The condition coefficient "K" of fishes was predicted using the following relationship after Le Cren (1951) and Ricker (1975):

$$
\mathrm{K}=\mathrm{W} / \mathrm{L}^{3 *} 100
$$

Where: $\mathrm{K}=$ condition factor, $\mathrm{W}=$ fish weight in grams and $\mathrm{L}=$ fish standard length in centimeters.

\section{Reproduction:}

\section{1-Sex determination:}

Gonads were examined with the naked eye regarding to the sexual maturity of the samples. Gonads with smooth exterior belong to males while gonads with rough exterior belong to females.

Gonads were taken out very carefully, weighed to the nearest grams and preserved in labeled vials containing 5\% formalin for subsequent examination.

2-Gonadosomatic index (GSI):

The fish gonadosomatic index was calculated following the equation cited by Parameswarn et al. (1974): $\quad$ GSI= (Weight of gonads / Total weight of fish) * 100

3-Absolute fecundity:

The gravimetric method was used for calculating fecundity (Murua et al., 2003). Known weight subsamples from the anterior, middle and posterior regions of both tubules were cut (James et al., 1978). Subsamples were spread evenly in a petri dish using a few drops of water, counting of the ova was carried out by eye and the average number of the three subsamples was obtained.

The absolute fecundity of each individual female fish was calculated by the following formula:

Absolute fecundity $=($ Total weight of ovary $/$ Weight of subsample $) *$ No. of ova in the subsample

4-Length, body weight and fecundity relationship:

The relationship of standard length and fecundity was estimated using the formula given by Bagenal (1978).

$$
\mathrm{F}=\mathrm{a} \mathrm{Sl}^{\mathrm{b}}
$$

When fish weight was considered, the following equation was used:

$$
\mathrm{F}=\mathrm{a} \mathrm{W}^{\mathrm{b}}
$$

Where:

$\mathrm{F}=$ absolute fecundity.

$\mathrm{Sl}=$ standard length in centimeters.

$\mathrm{W}=$ fish weight in grams.

Regression constants $=\mathrm{a}$ and $\mathrm{b}$. 


\section{RESULTS}

\section{!. Growth:}

1.1 -Length-weight relationship:

Among other biological parameters, the length-weight relationship determines the normality in growth and variation in condition of . niloticus. The resulting formulae were found to be as the following:

For males:

$\log \mathrm{W}=-0.8861+2.5842 \log \mathrm{L}$

$\left(\mathrm{r}^{2}=0.99\right)$

Where $\mathrm{L}=$ Standard length of fish in centimeter, $\mathrm{W}=$ weight of fish in gram and $\mathrm{r}^{2}$ is the coefficient of determination. Fig. 1 represents this relationship. The high value of the coefficient of determination is a good measure for how much the variation in weight is correlated to variation in length. The value of $b$ constant equals to 2.5842 , thus there is a negative allometric growth of males.

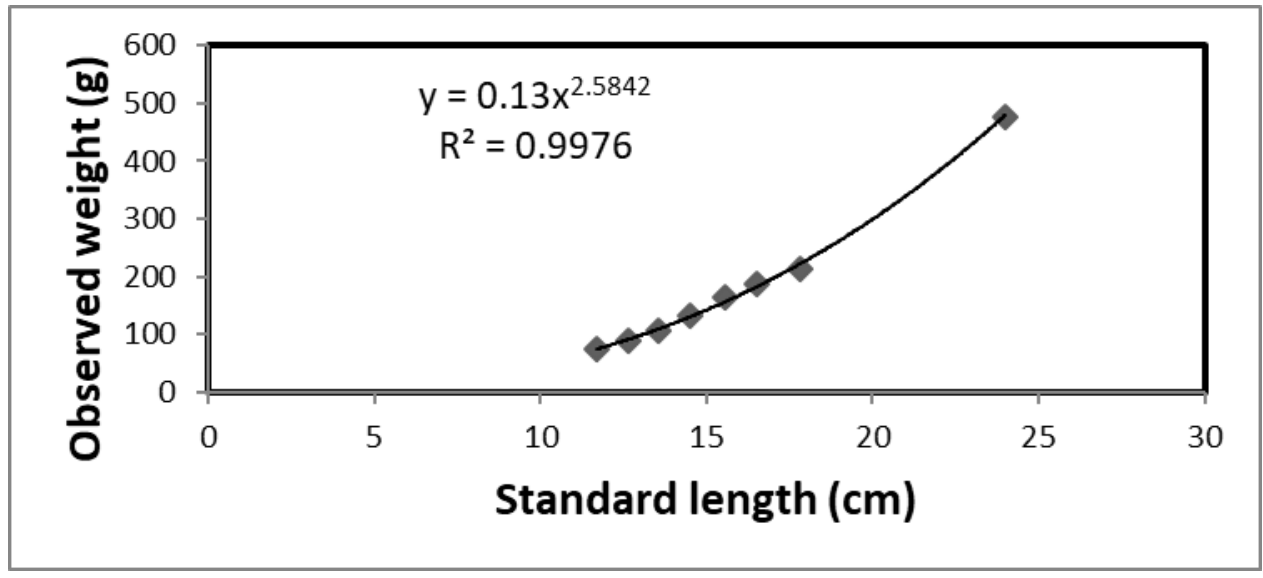

Fig. 1: Relationship between standard length and observed weight of males of O.niloticus.

And for females:

$\log \mathrm{W}=-1.1319+2.7994 \log \mathrm{L}$

$\left(\mathrm{r}^{2}=0.99\right)$

Where $\mathrm{L}=$ Standard length of fish in centimeter, $\mathrm{W}=$ weight of fish in gram and $\mathrm{r}^{2}$ is the coefficient of determination.

Fig.2 represents this relationship. The high value of the coefficient of determination which is comparable to that of males is a good measure for how much the variation in weight is correlated to variation in length. The value of $b$ constant equals to .7994, thus there is also a negative allometric growth of females. 


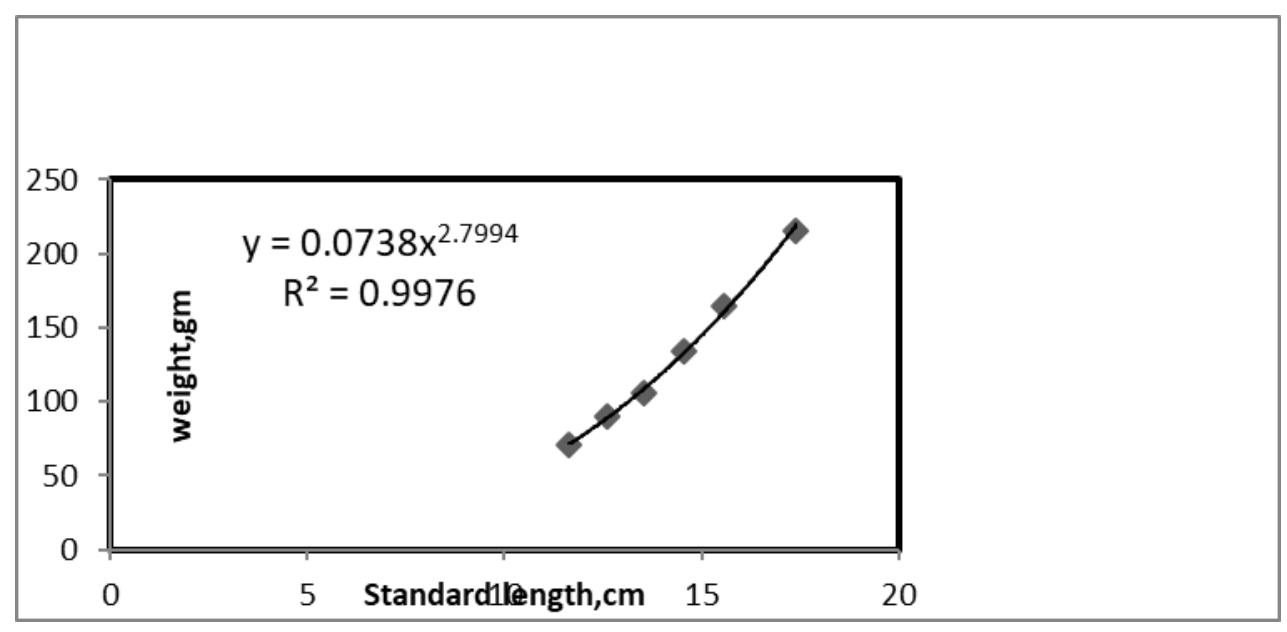

Fig. 2: Relationship between standard length and observed weight of females of O.niloticus.

\section{2-Seasonal variation of weight-length slope (b) value:}

For males:

It was found that, the highest (b) value 3.12 was recorded during autumn and the lowest value 2.16 was found during spring (Table 1).

And for females:

It was found that, the highest (b) value 2.83 was recorded during summer, followed by winter 2.8 and the lowest value 2.14 was found during spring (Table 2).

Table 1: Seasonal variation of length-weight slope (b) value of males of $O$. niloticus.

\begin{tabular}{|l|l|l|l|}
\hline Season & Temp. & No. of fishes & Length-weight slope (b) value \\
\hline Winter & 24.2 & 43 & 3 \\
\hline Spring & 27.6 & 66 & 2.16 \\
\hline Summer & 34.7 & 66 & 2.7 \\
\hline Autumn & 30.3 & 61 & 3.12 \\
\hline
\end{tabular}

Table 2: Seasonal variation of Length-weight slope (b) value of females of $O$. niloticus.

\begin{tabular}{|l|l|l|l|}
\hline Season & Temp. & No. of fishes & Length-weight slope (b) value \\
\hline Winter & 24.2 & 47 & 2.8 \\
\hline Spring & 27.6 & 24 & 2.14 \\
\hline Summer & 34.7 & 24 & 2.83 \\
\hline Autumn & 30.3 & 29 & 2.48 \\
\hline
\end{tabular}

\section{3- Relationship between age, length and weight:}

\section{For males:}

Table 3 and Figs. 3 and 4 represent the relationship between age and either standard length or weight of males of $O$. niloticus. They were found to be logarithmic. As 
indicated, $\mathrm{r}^{2}$ reached 0.83 in the relation with length, while reached 0.84 in the relation with weight, predicting positive relationship between age, length and weight of males.

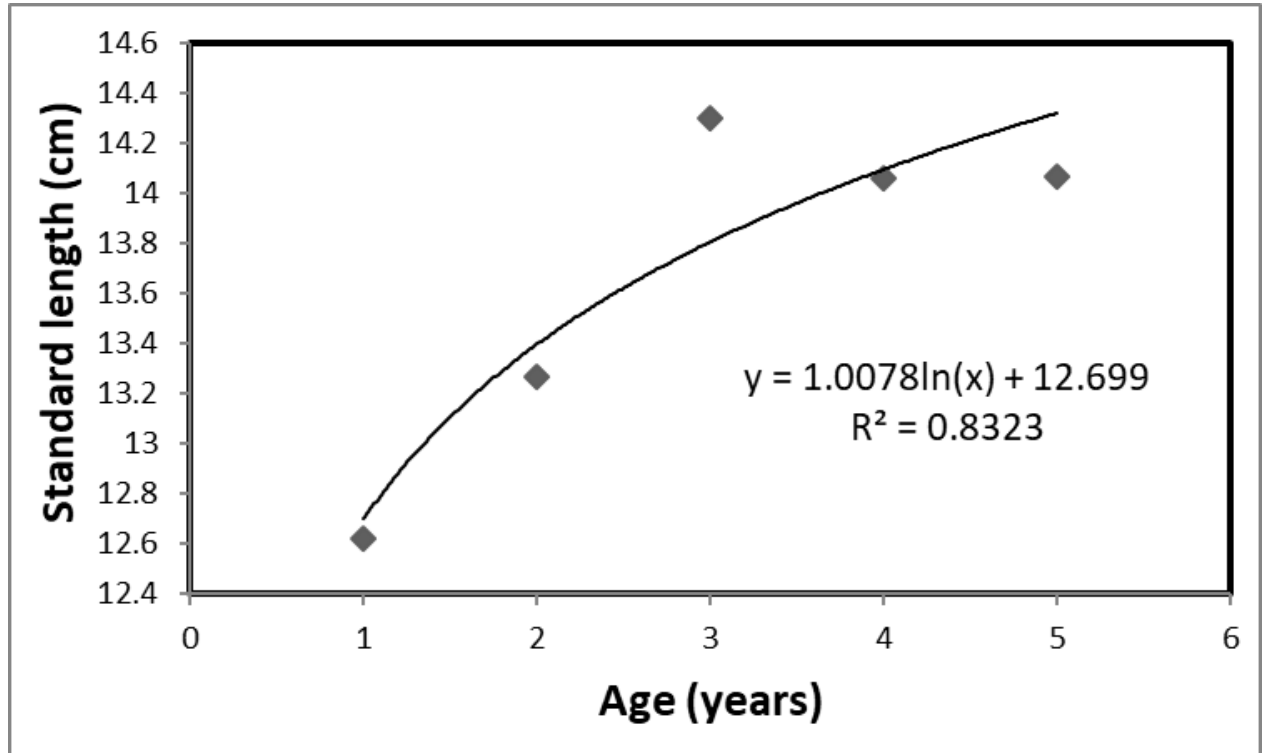

Fig. 3: Relationship between age (years) and standard length $(\mathrm{cm})$ of males of O.niloticus.

Table 3: Relationship between age, standard length and weight of males of $O$. niloticus.

\begin{tabular}{|l|l|l|l|}
\hline Age (years) & No. of fishes & $\begin{array}{l}\text { Average standard length }(\mathrm{cm}) \\
(\text { Mean } \pm \text { SD) }\end{array}$ & $\begin{array}{l}\text { Average weight }(\mathrm{g}) \\
(\text { Mean } \pm \text { SD) }\end{array}$ \\
\hline I & 45 & $12.62 \pm 1.11$ & $92.82 \pm 26.72$ \\
\hline II & 95 & $13.27 \pm 1.15$ & $104.96 \pm 27.73$ \\
\hline III & 68 & $14.3 \pm 1.82$ & $126.26 \pm 55.54$ \\
\hline IV & 19 & $14.06 \pm 1.51$ & $123.26 \pm 39.38$ \\
\hline V & 9 & $14.07 \pm 1.35$ & $122.33 \pm 29.53$ \\
\hline
\end{tabular}

\section{For females:}

Table 4 and Figs. $5 \& 6$ represent the relationship between age and either standard length or weight of females of $O$. niloticus. They were found to be logarithmic. As indicated, $\mathrm{r}^{2}$ reached 0.92 in the relation with length, while reached 0.88 in the relation with weight, predicting good association between age, length and weight of females comparing to males. 


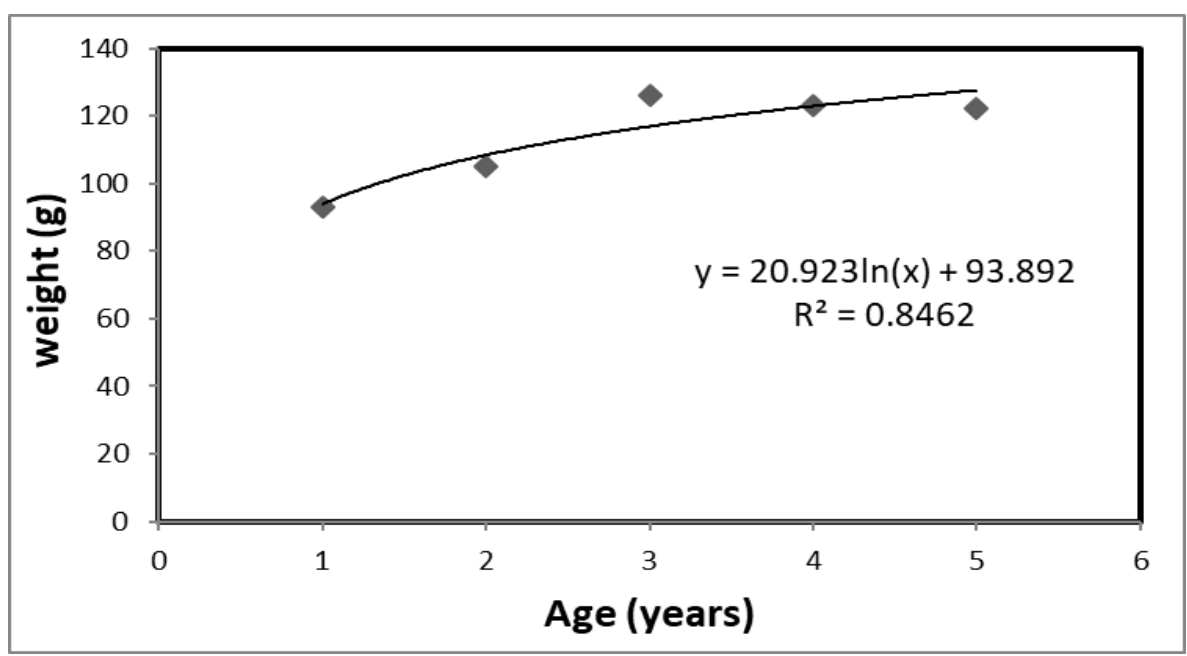

Fig.4: Relationship between age (years) and weight (g) of males of O.niloticus.

Table 4: Relationship between age, standard length and weight of females of $O$. niloticus

\begin{tabular}{|l|l|l|l|}
\hline Age (years) & No. of fishes & $\begin{array}{l}\text { Average standard length }(\mathrm{cm}) \\
(\text { Mean } \pm \text { SD) }\end{array}$ & $\begin{array}{l}\text { Average weight }(\mathrm{g}) \\
(\text { Mean } \pm \text { SD) }\end{array}$ \\
\hline I & 7 & $12.01 \pm 0.46$ & $77.43 \pm 7.63$ \\
\hline II & 54 & $12.91 \pm 1$ & $96.8 \pm 18.78$ \\
\hline III & 41 & $12.95 \pm 0.84$ & $97.73 \pm 21.26$ \\
\hline IV & 16 & $13.51 \pm 1.3$ & $108.63 \pm 32$ \\
\hline V & 6 & $13.42 \pm 1$ & $104.33 \pm 17.63$ \\
\hline
\end{tabular}

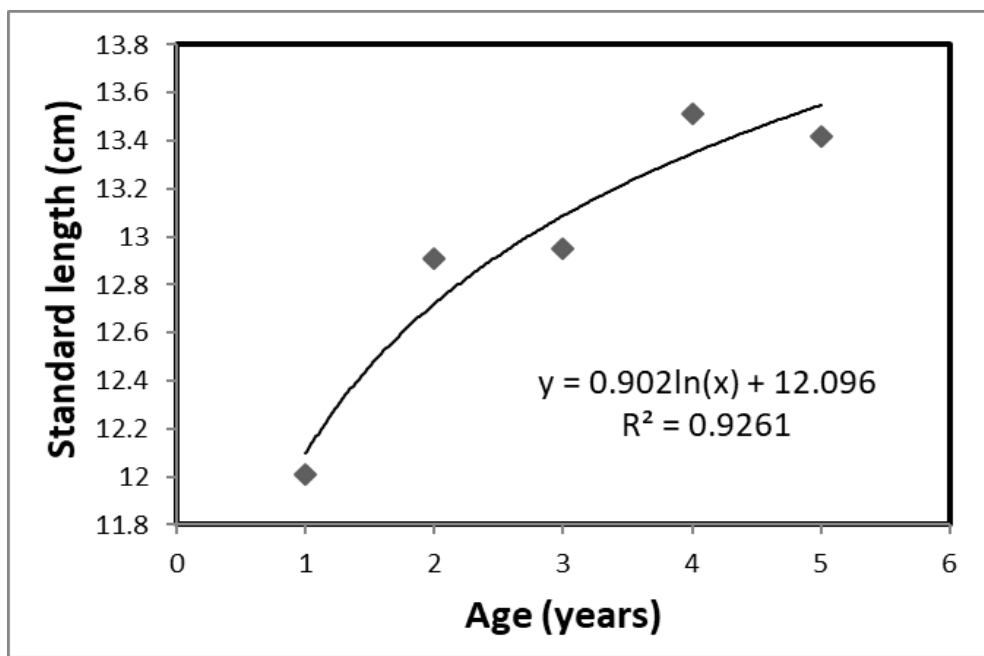

Fig.5: Relationship between age (years) and standard length $(\mathrm{cm})$ of females O.niloticus. 


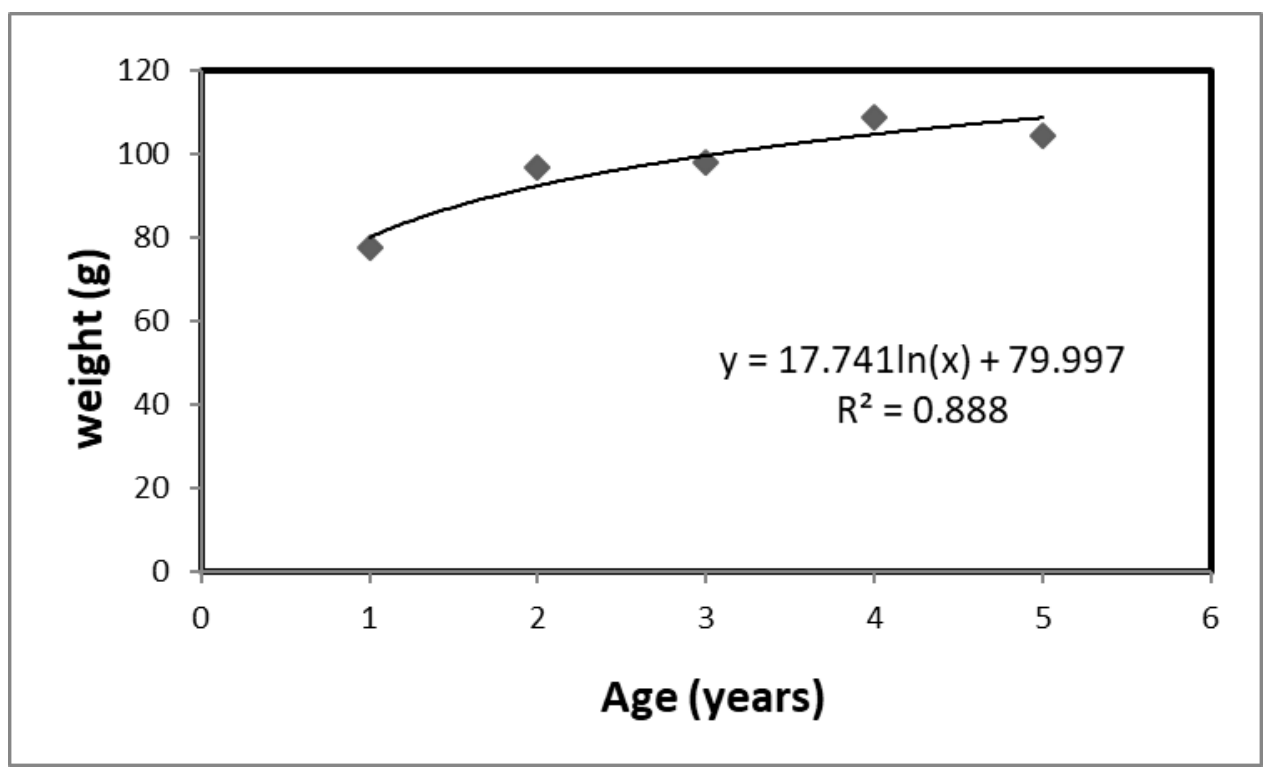

Fig. 6: Relationship between age (years) and weight (g) of females of O.niloticus.

\section{Condition coefficient:}

2.1-Relationship between age and condition coefficient $(\mathrm{K})$ :

The condition coefficient varied with different age groups as follows:

For males:

The highest value of fish condition was at age group I $(K=4.62)$, while the lowest value was reached at age group III ( $\mathrm{K}=4.32)$ (Fig. 7).

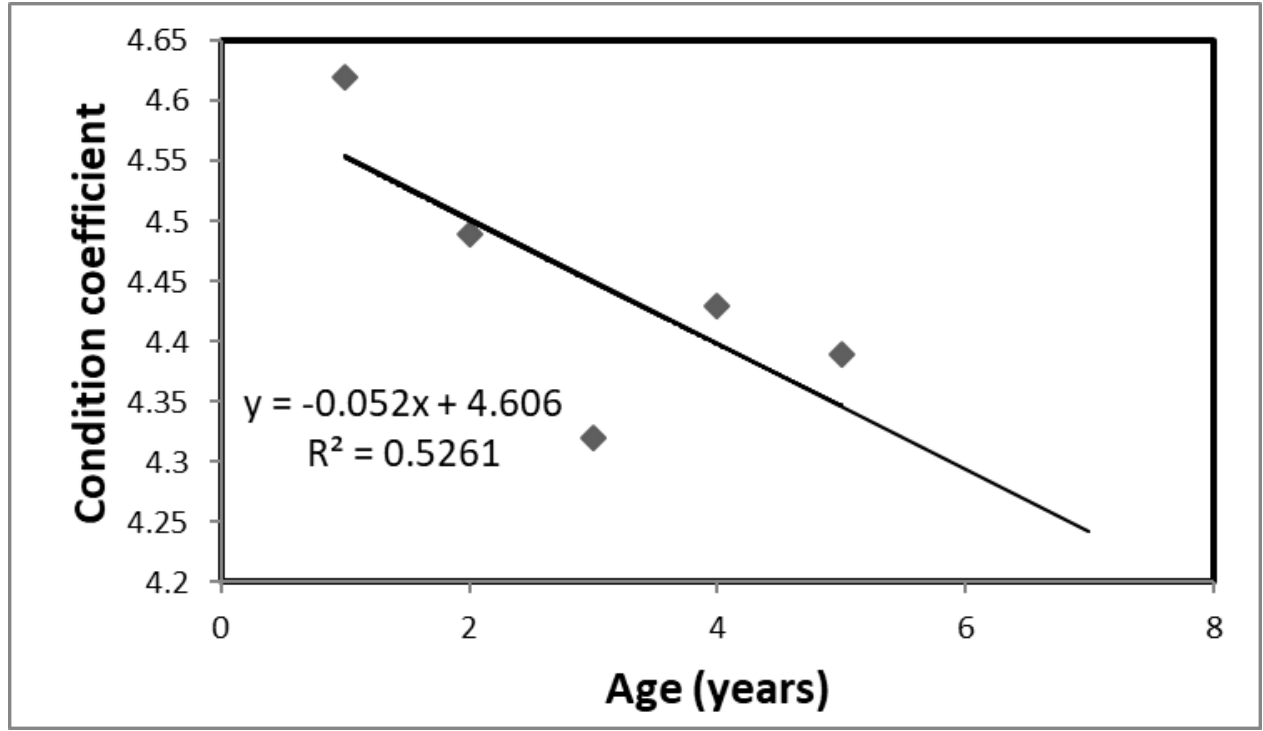

Fig. 7: Relationship between age (years) and Condition coefficient of males of O.niloticus. 


\section{For females:}

The highest value of fish condition was at age group III $(\mathrm{K}=4.5)$, while the lowest value was reached at age group $\mathrm{V}(\mathrm{K}=4.32)$ (Fig. 8).

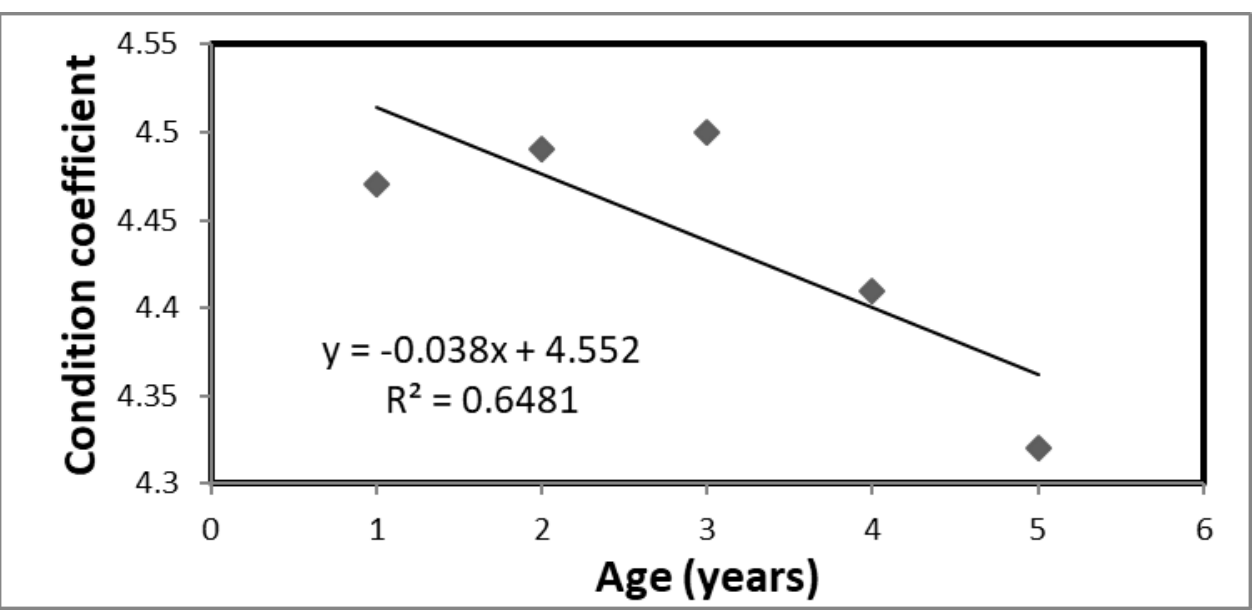

Fig.8: Relationship between age (years) and Condition coefficient of females of O.niloticus.

2.2-Monthly variation of condition coefficient $(\mathrm{K})$ :

For males:

Fig. 9 shows the variation in value of $\mathrm{K}$ through different months. The $\mathrm{K}$ value peaked in April, June, August, and December for males.

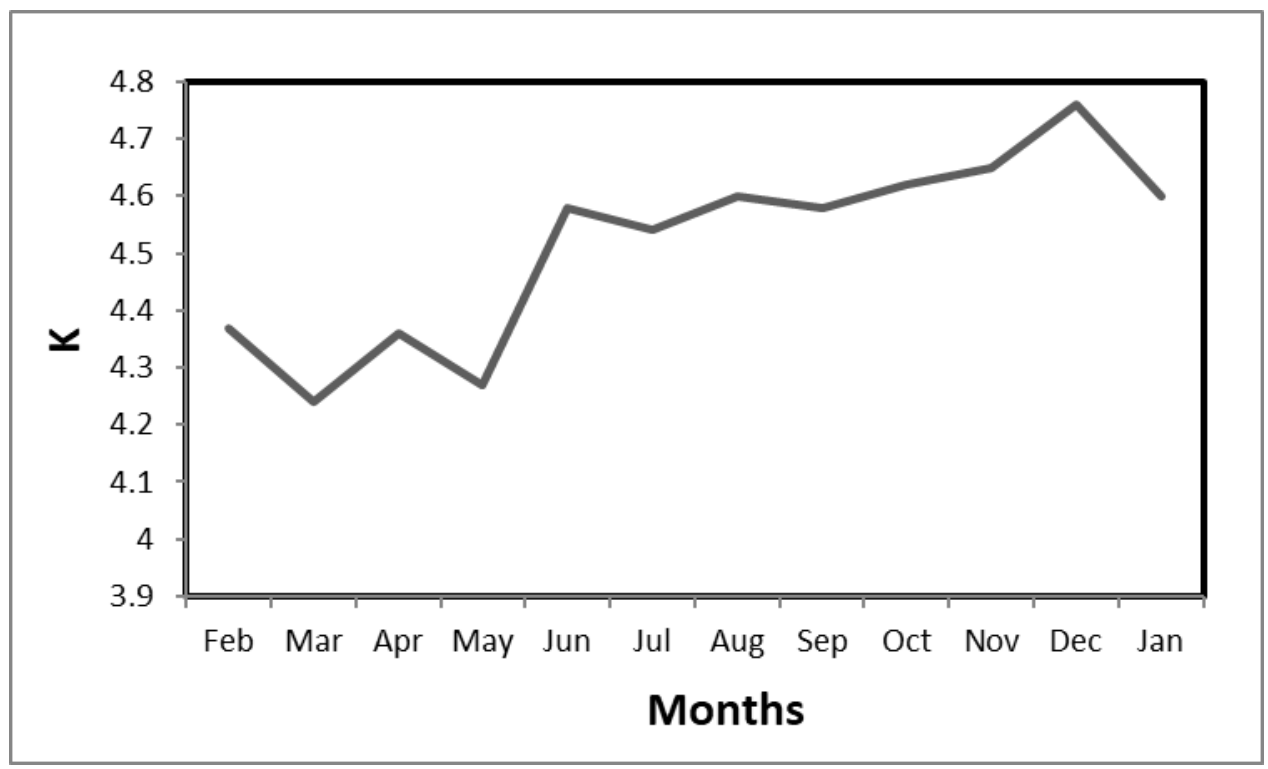

Fig. 9: Monthly variation of condition coefficient of males of O.niloticus. 


\section{For females:}

Fig. 10 shows the variation in value of $\mathrm{K}$ through different months. The $\mathrm{K}$ value peaked in April, June, August, October, and December for females.

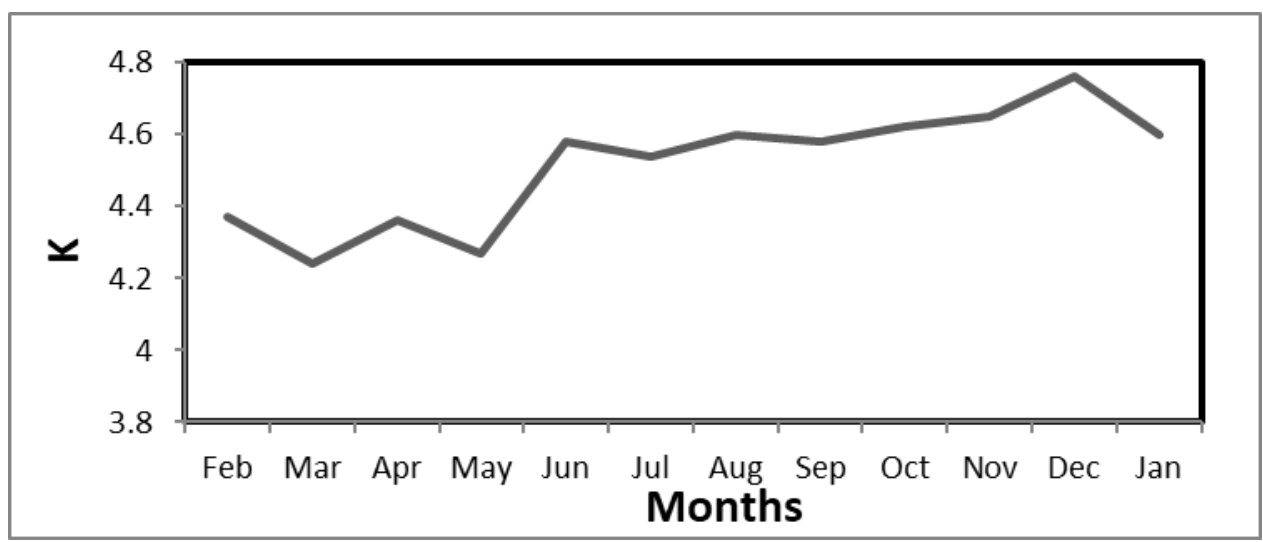

Fig. 10: Monthly variation of condition coefficient of females of O.niloticus

\section{3-Seasonal variation of condition coefficient (K):}

For males:

The values of $\mathrm{K}$ were comparable in winter and summer and the highest value was achieved in autumn, while the lowest value was in spring for males (Fig. 11).

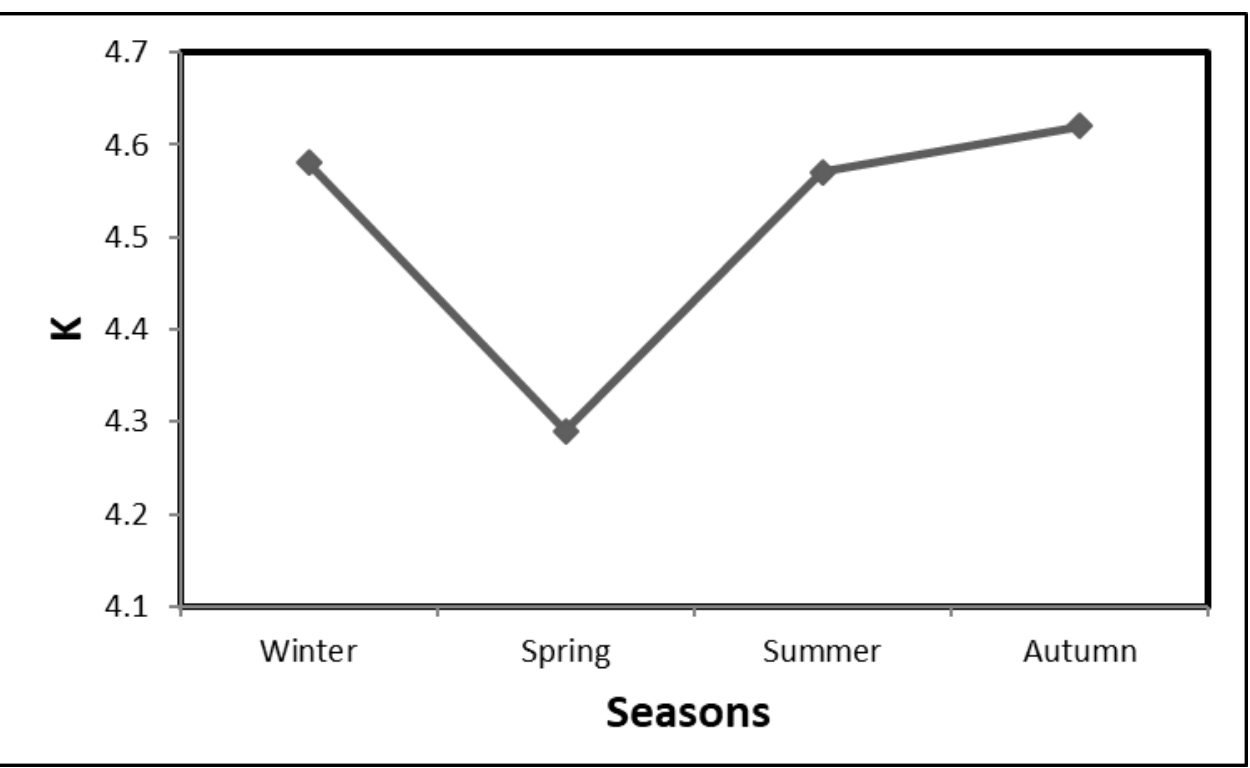

Fig. 11: Seasonal variation of condition coefficient of males of O.niloticus

For Females:

The values of $\mathrm{K}$ were comparable in winter and autumn and the highest value was achieved in summer, while the lowest value was in spring for females (Fig. 12). 


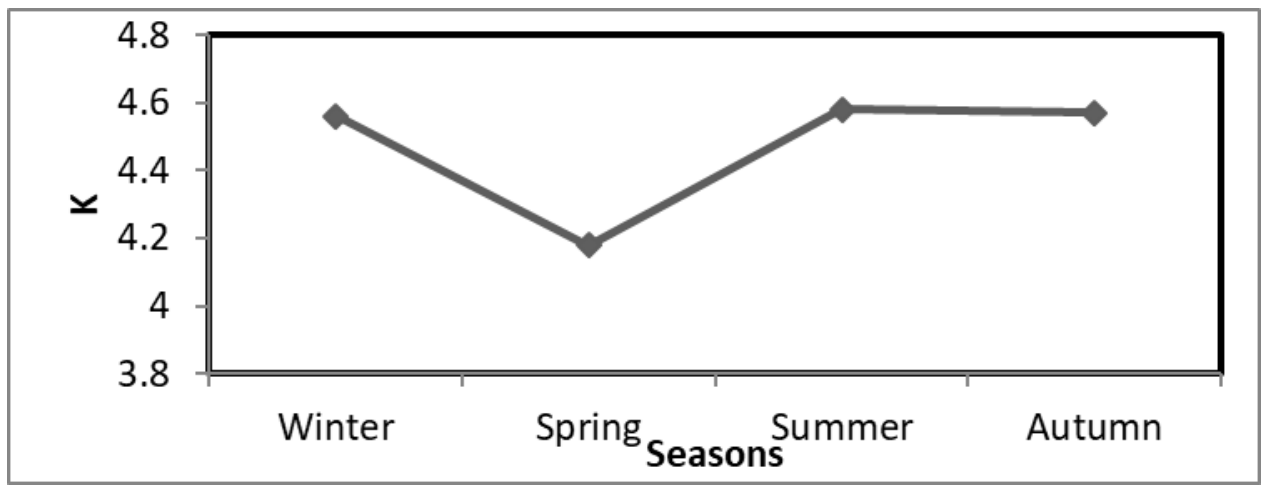

Fig. 12: Seasonal variation of condition coefficient of females of O.niloticus.

\section{Reproduction:}

3.1-Relationship between standard length and gonadosomatic index (GSI):

For males:

Fig. 13 illustrates the relationship between standard length and GSI of males of $O$. niloticus. It was found to be linear with direct proportion. As indicated, $\mathrm{r}^{2}$ reached 0.92 , predicting good association between standard length and GSI of males. The highest spawning peak of males was recorded at length interval 23-24.

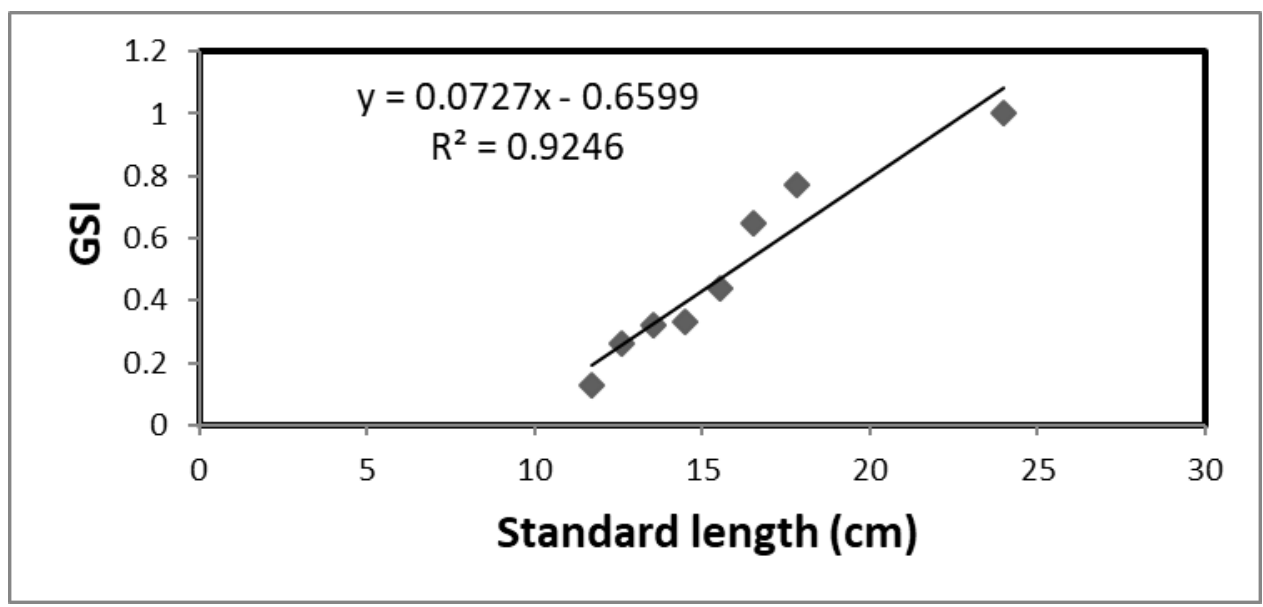

Fig. 13: Relationship between standard length $(\mathrm{cm})$ and GSI of males of O.niloticus.

\section{For females:}

Fig. 14 illustrates the relationship between standard length and GSI of females of $O$. niloticus. GSI values increased gradually till reaching the highest spawning peak that corresponds $13-14 \mathrm{~cm}$ then declined again with the following length intervals. 


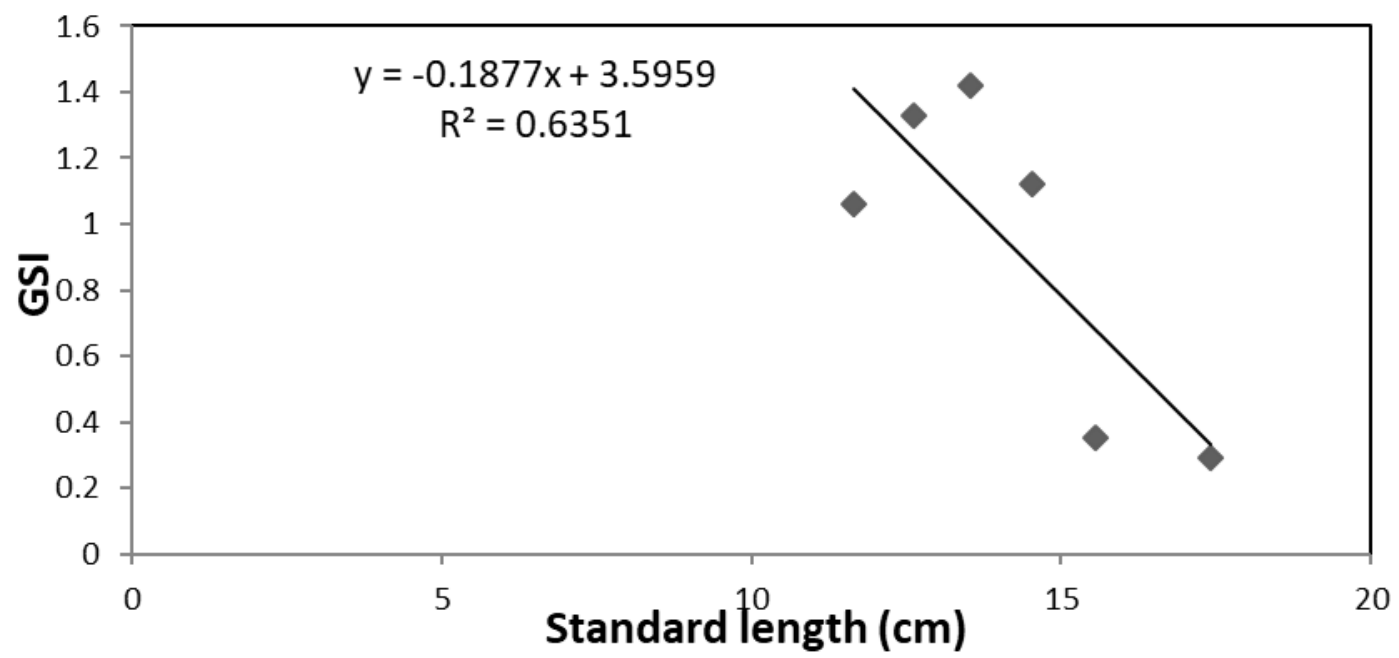

Fig. 14: Relationship between standard length $(\mathrm{cm})$ and GSI of females of O.niloticus

\section{2-Relationship between age and gonadosomatic index (GSI):}

For males:

GSI value has two spawning peaks, the lowest one corresponds age group I and the highest was corresponding to age group V (Table 5).

Table 5: Relationship between age (years) and GSI of males of O.niloticus.:

\begin{tabular}{|l|l|l|}
\hline Age groups & No. of fishes & Average GSI \pm SD \\
\hline I & 45 & $0.22 \pm 0.2$ \\
\hline II & 95 & $0.24 \pm 0.22$ \\
\hline III & 68 & $0.38 \pm 0.34$ \\
\hline IV & 19 & $0.37 \pm 0.4$ \\
\hline V & 9 & $0.58 \pm 0.42$ \\
\hline
\end{tabular}

\section{For females:}

GSI value has two spawning peaks the lowest one corresponds age group III and the highest was corresponding to age group II (Table 6). 
Table 6: Relationship between age (years) and GSI of females of O.niloticus.:

\begin{tabular}{|l|l|l|}
\hline Age groups & No. of fishes & Average GSI \pm SD \\
\hline I & 7 & $1.19 \pm 0.97$ \\
\hline II & 54 & $1.34 \pm 1.37$ \\
\hline III & 41 & $1.11 \pm 1.87$ \\
\hline IV & 16 & $1.31 \pm 0.9$ \\
\hline V & 6 & $1.16 \pm 1.7$ \\
\hline
\end{tabular}

\section{3-Monthly variation of gonadosomatic index (GSI): \\ For males:}

Fig. 15 illustrates the variation of GSI of males with different months of the study period. The gonadosomatic index varied between 0.09 to 0.71 with three peaks, the highest in February 0.71, medium in June 0.33 and the lowest in August 0.26. Thus the fish spawned for several months with three spawning peaks.

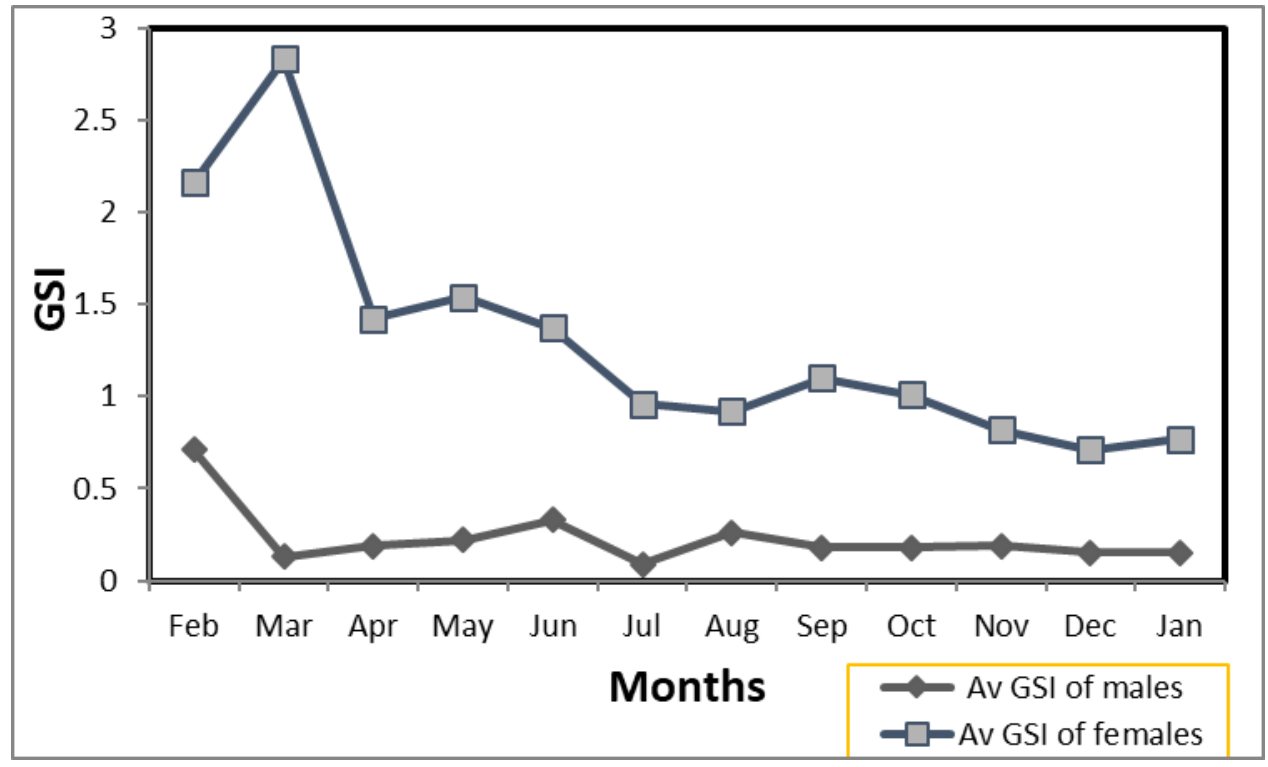

Fig. 15: Monthly variation of GSI of males and females of O.niloticus.

\section{For females:}

Fig. 15 illustrates the variation of GSI of females with different months of the study period. The gonadosomatic index varied $\mathrm{f} 0.71$ to 2.83 with three peaks, the highest in March 2.83, medium in May 1.54 and the lowest in September 1.1. Thus the fish spawned for several months with three spawning peaks. 


\section{4-Seasonal variation of gonadosomatic index (GSI):}

For males:

The gonadosomatic index varied between 0.18 to 0.34 with two peaks, the highest in winter 0.34 and the lowest in summer 0.23 (Fig.16).

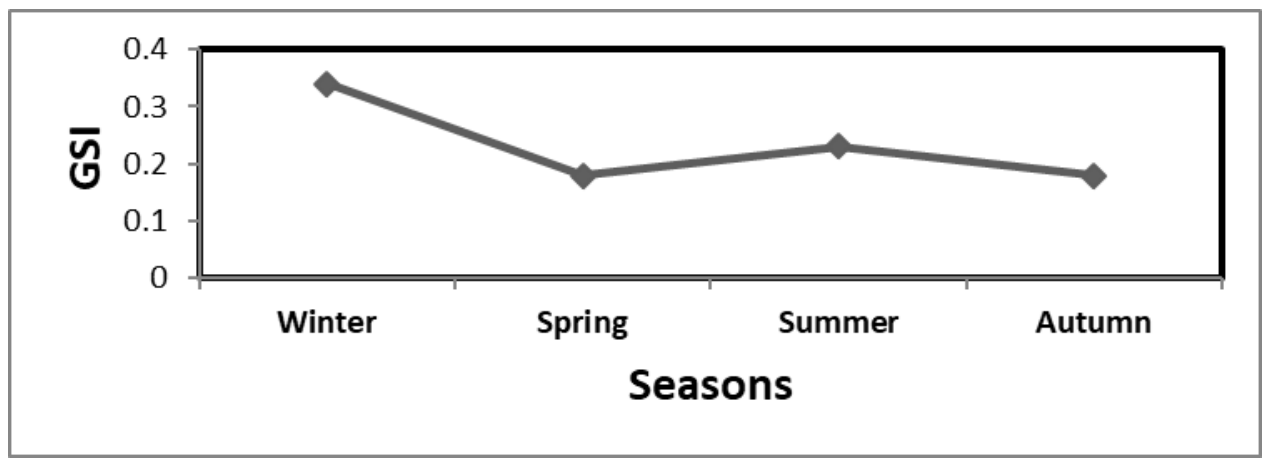

Fig. 16: Seasonal variation of GSI of males of O.niloticus.

\section{For females:}

The gonadosomatic index varied fr0.98 to 1.93 with one peak in spring 1.93 (Fig. 17).

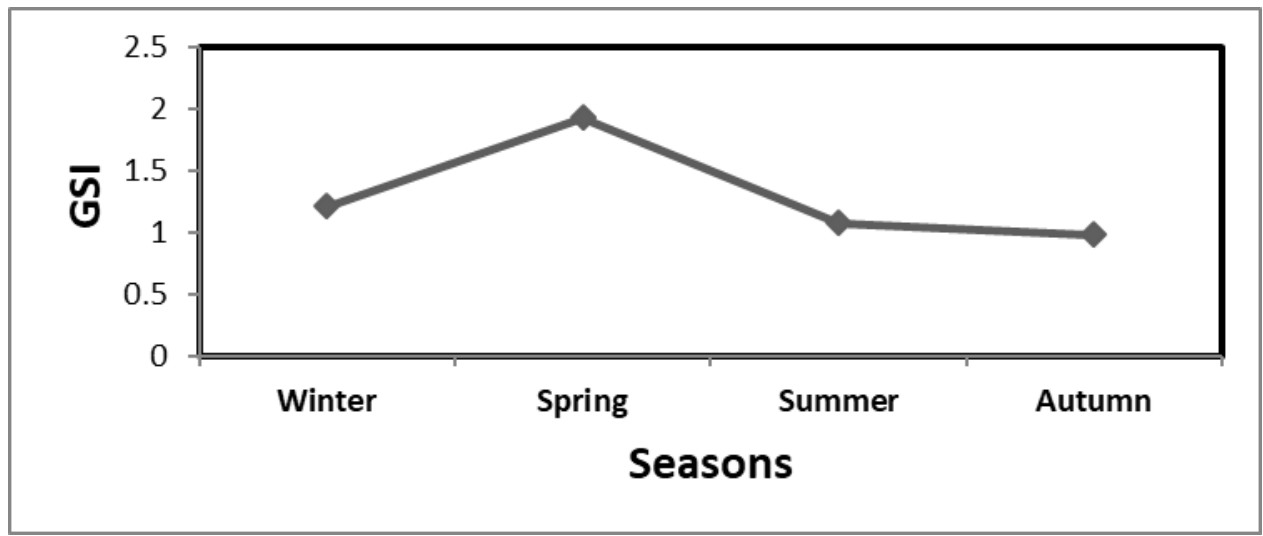

Fig.17: Seasonal variation of GSI of females of O.niloticus

\section{5- Relationship between standard length and fecundity:}

Fig. 18 illustrates the relationship between standard length and fecundity of $O$. niloticus. It was found to be exponential. As indicated, $\mathrm{r}^{2}$ reached 0.93 , predicting good association between standard length and fecundity. 


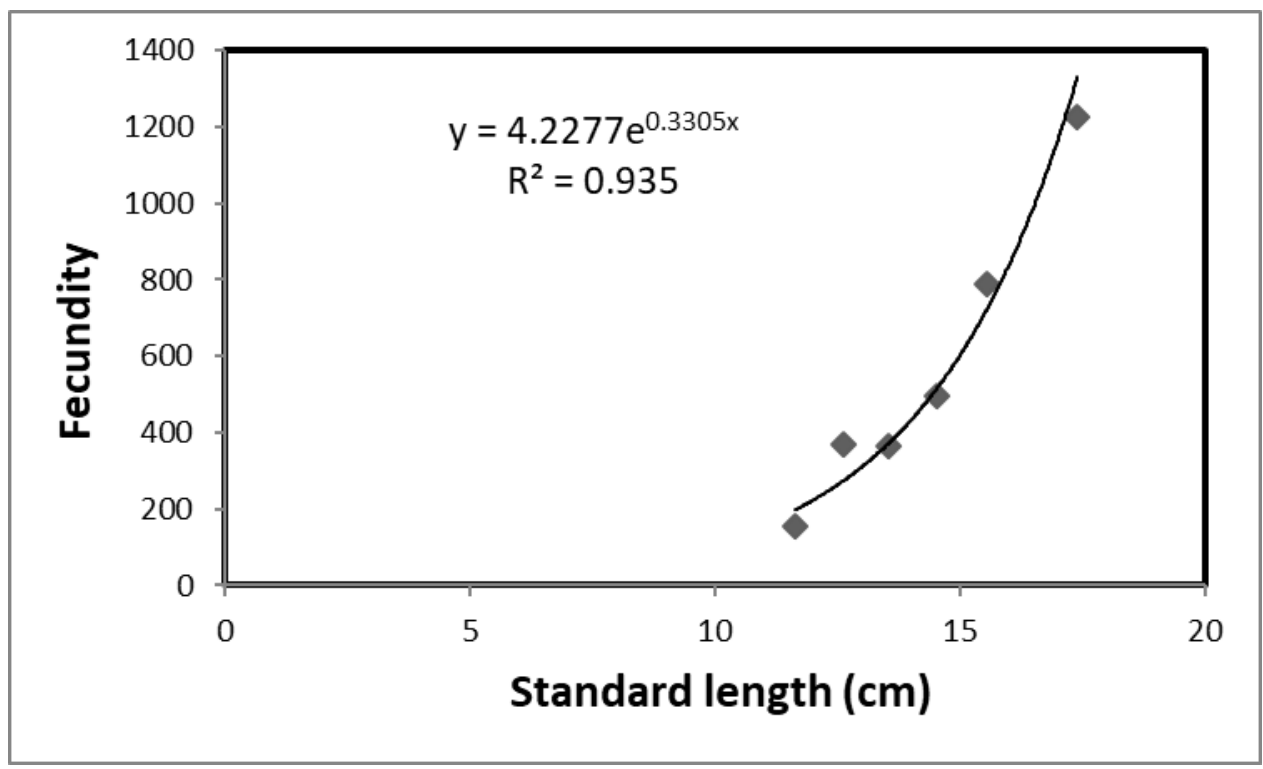

Fig. 18: Relationship between standard length $(\mathrm{cm})$ and fecundity of O.niloticus.

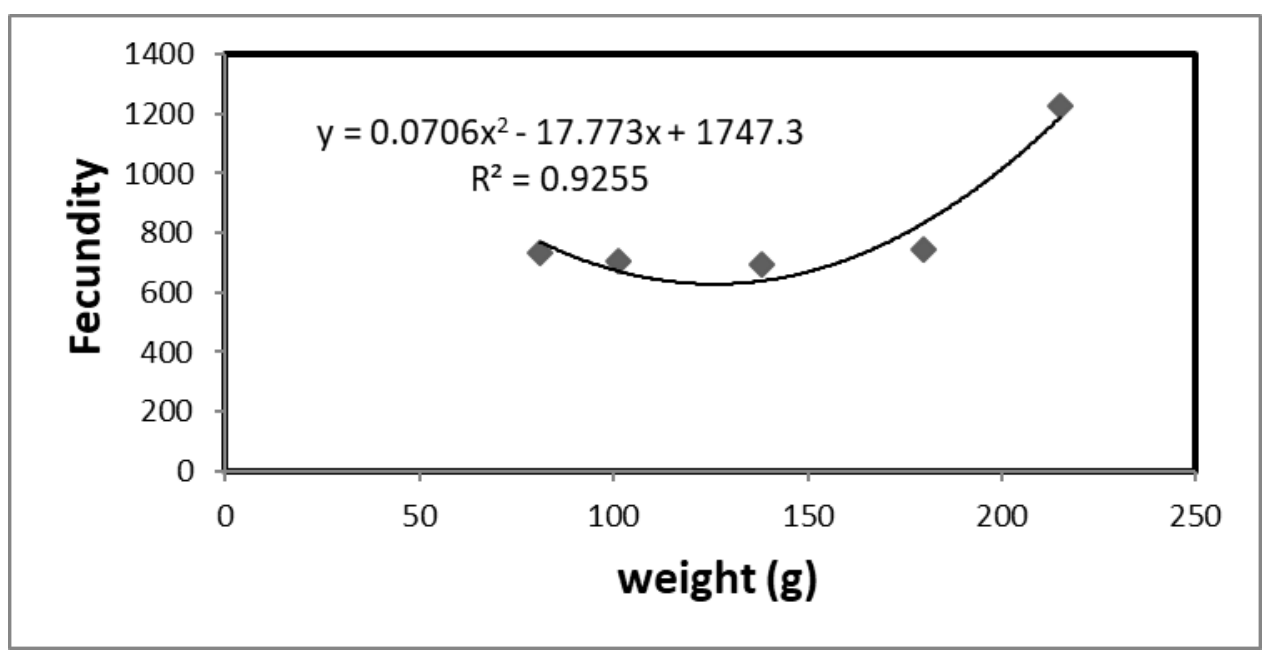

Fig. 19: Relationship between weight (g) and fecundity of O.niloticus.

\section{6- Relationship between weight and fecundity:}

Fig. 19 illustrates the relationship between weight and fecundity of $O$. niloticus. It was found to be polynomial. As indicated, $\mathrm{r}^{2}$ reached 0.92 , predicting good association between weight and fecundity of fishes.

\section{7- Relationship between age and fecundity:}

The highest number of ova was achieved at age group V $(\mathrm{F}=686)$, age groups II, III and IV were comparable with high values too and age group I had the lowest value of fecundity $(F=537)$ (Table 7). 
Table 7: Relationship between age (years) \& fecundity of O.niloticus.

\begin{tabular}{|l|l|l|}
\hline Age groups & No. of fishes & Average fecundity \pm SD \\
\hline I & 7 & $537 \pm 871$ \\
\hline II & 54 & $635 \pm 451$ \\
\hline III & 41 & $674 \pm 652$ \\
\hline IV & 16 & $653 \pm 435$ \\
\hline V & 6 & $686 \pm 366$ \\
\hline
\end{tabular}

\section{8-Monthly variation of fecundity:}

The fecundity varied between 359 to 1198 with four peaks, the highest in February 1198, medium in May 740, then October 661 and the lowest in January 522. Thus fishes contained large numbers of ova through several months with four peaks (Fig. 20).

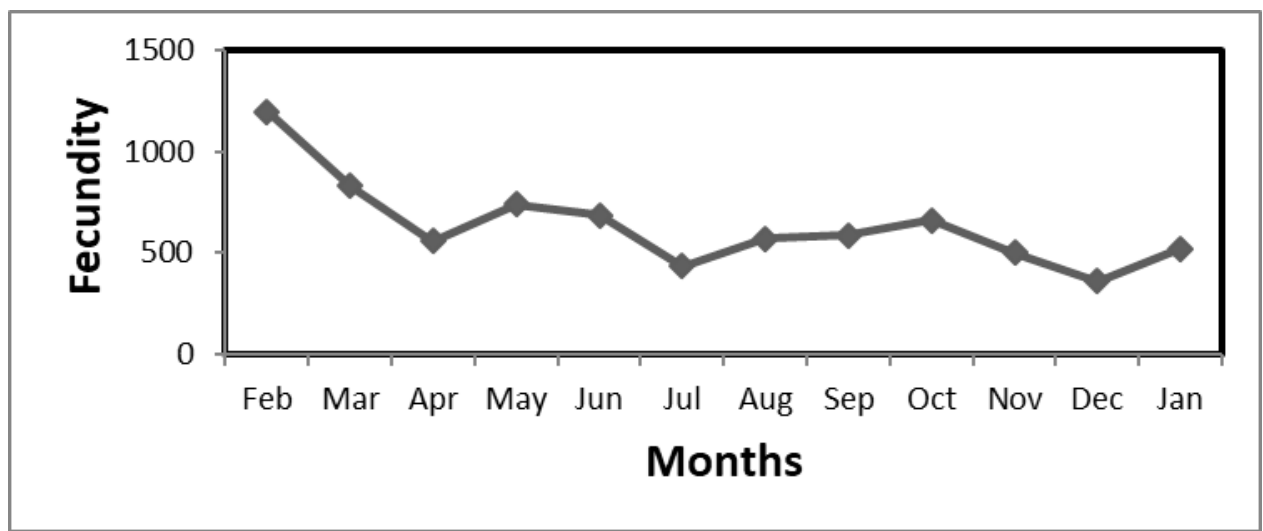

Fig. 20: Monthly variation of fecundity of O.niloticus.

\section{9-Seasonal variation of fecundity}

The fecundity varied 646 to 742 . The highest value in winter then declined slightly in the following seasons. The relationship is linear with an indirect proportion and $\mathrm{r}^{2}=0.99$ (Fig. 21).

\subsection{0-Summer variation of fecundity:}

Table 8 illustrates the change in fecundity with different temperatures of summer months during the study period. The fecundity varied between 436 to 687 . The highest value in June was 687 then declined in July to 436 and increased again in August to 571. When fecundity was represented in association with variation of temperature (Fig. 22), it showed a power association with $\mathrm{r}^{2}=0.973$. This could be equated to the critical temperature with the lowest fecundity. That was found to be 180 eggs at 38.75 degrees. 


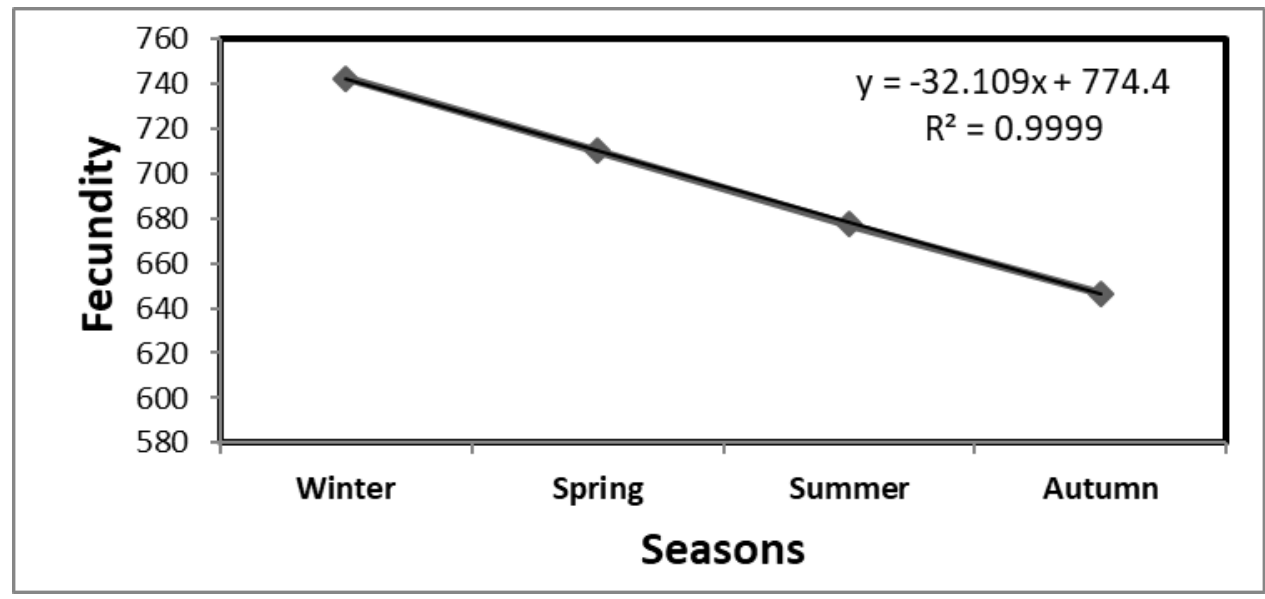

Fig. 21: Seasonal variation of fecundity of O.niloticus.

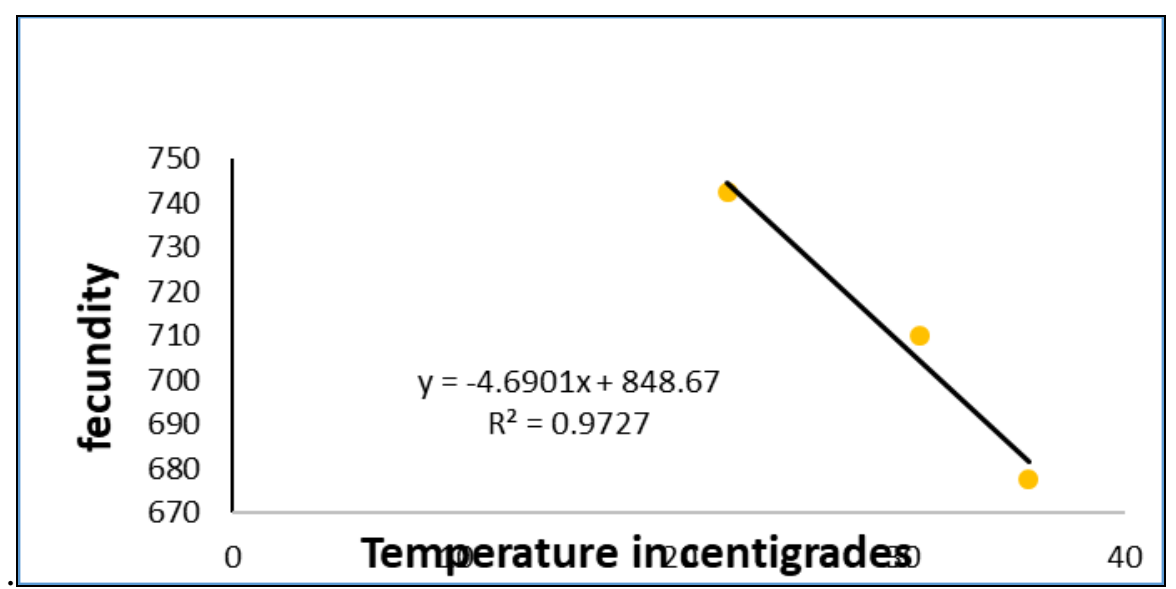

Fig.22: Variation of fecundity of O.niloticus. with temperature.

Table 8 : Summer variation of fecundity of O.niloticus.

\begin{tabular}{|l|l|l|l|}
\hline Month & Temp $\left({ }^{\circ}\right.$ c $)$ & No. of fishes & Average fecundity \pm SD \\
\hline Jun & 33.5 & 8 & $687 \pm 1277$ \\
\hline Jul & 35 & 5 & $436 \pm 469$ \\
\hline Aug & 35.5 & 7 & $571 \pm 422$ \\
\hline
\end{tabular}

\subsection{1-Annual variation of fecundity:}

Table 9 illustrates the annual variations of fecundity over the spent four years prior to the study. The fecundity varied between 525 to 637 . The lowest value was recorded in 2014 $(F=525)$ then increased dramatically till reaching the highest value in $2018(\mathrm{~F}=637)$. 
Table 9: Annual change in fecundity of O.niloticus.

\begin{tabular}{|l|l|}
\hline Years & Average fecundity \\
\hline 2014 & 525 \\
\hline 2015 & 525 \\
\hline 2016 & 530 \\
\hline 2017 & 550 \\
\hline 2018 & 637 \\
\hline
\end{tabular}

\section{DISCUSSION}

Tilapias acceptability as a food source is known all over the world, as well as their participation as a source of national income for many countries and their tolerance to a wide range of environmental conditions which is the main reason for their spread all over the world (FAO, 2020). Consequently, previous studies focused on the biological and environmental conditions (Khallaf et al., 2003; Tsadik and Bart, 2007; Khallaf et al., 2019).

The relationship between total and standard lengths for males and females gave linear relationships, values of $\mathrm{r}^{2}$ equaled to 0.93 and 0.97 , respectively. The weight-length exponent, here, was found to be 2.5842 and 2.7994 for males and females, respectively. This indicates that $O$. niloticus in Bahr Shebeen Canal relatively were not in their best conditions throughout this study period. Many factors can affect $b$ values such as biological, chemical, physical variables like salinity, temperature, or food, stomach fullness, stage of maturity and sex (Ricker, 1975; Olurin and Aderibigbe, 2006; Sarkar et al., 2013). i.e., if the fish gets thinner, $\mathrm{n}$ (or b) will be less than 3 and if $\mathrm{n}>3$, the fish becomes heavier for its length as it grows larger (Ricker, 1975). Le Cren (1951) recorded that isometric growth where $b=3$ is rare in a majority of fishes.

Seasonal variation in the $b$ value also was observed through this study. Males have the highest value of $b$ parameter through autumn $(b=3.12)$ while females have their highest value of $b$ parameter through summer $(b=2.83)$. This could be attributed to seasonal variation of food availability, feeding rate, gonad development, and spawning period. In accordance, Goncalves et al. (1997) and Özaydin et al. (2007) reported that parameter b may vary seasonally, daily, or between habitats.

The use of rings or bands on boney structures of tilapias, as growth annuli in Nilotic tilapias was established earlier by Latif and Khallaf (1987) and Khallaf (1992). The examination of annuli on fish scales, in this study, showed that the longevity of both males and females of $O$. niloticus is represented by five age groups. This agrees with the findings of Khallaf et al. (2016a) and Khallaf et al. (2019). When growth in length was considered, each followed a semi-log relationship with a 
high coefficient of determination ( 0.832 for males and 0.926 for females). Figures ( $3 \& 5$ ), showed a rise in growth rate in length at age group $3 \& 4$ for males and females, respectively. This was also noticed in figs. (4) and (6) for variations in weight with age. Apparently, this might be due to spawning activity and increase in gonad weight. In addition, the length range for those age groups was found to lie between 12.6 to $14.3 \mathrm{~cm}$ for males, and from 12 to $13.5 \mathrm{~cm}$ for females. Since the fish were caught by fishermen gears, this showed that there is a tendency to catch lower fish size, which is another factor in the variability of growth in length.

Males condition coefficient varied between 4.32 to 4.62 as age increases. However, females $\mathrm{K}$ varied from 4.32 to 4.5 , and increasing gradually till its highest value at age group 3, then decreased at the following age groups. These variations might be attributed to the changes in gonad development and sexual maturation of both sexes. The value of $\mathrm{K}$ is affected also by age of fish, season, sex, stage of maturation, fullness of gut, amount of fat reserve, type of food consumed, and degree of muscular development (Barnham et al., 2003).

The monthly variations of $\mathrm{K}$ values for males have peaked in February, April, June, August, and December, respectively in an ascending order. Females have peaked through the same months in addition to a peak in October. This might be due to sexual activity with increase in gonads weight. When GSI is examined (Fig. 15), it illustrates that the months of February-March, May-June, and August-September show such activity. In general, when there will be sexual activity, the condition coefficient of fish is higher preparing for the subsequent event. Khallaf et al. (2016b) revealed that $O$. niloticus of BSC had the highest values of K during November, April and July only. These changes may be attributed to the change of duration of the study and the variations of water physicochemical parameters. Variations in $\mathrm{K}$ factor with seasons and pollution were also reported by Khallaf et al. (2003) in Shanawan drainage canal in Egypt.

For males of $O$. niloticus the seasonal $\mathrm{K}$ value ranged between 4.29 to 4.62 , decreasing on going from winter to spring, where it reached the lowest value, then increased again afterward till the highest value in autumn. This might be attributed to the prevalent ecological condition and not spawning, as the GSI value was the lowest in spring. Food availability usually influences the value of condition coefficient (Pope and Willis, 1996; Gallardo-Cabello et al., 2007).

The $\mathrm{K}$ value of females ranged between 4.18 to 4.58 , and decreased gradually from winter to autumn, but spring has recorded the lowest value also. This might be attributed to spawning of fishes when taking the GSI values into consideration. These results agree with Khallaf et al. (2019) who reported that seasonal variation of the condition coefficient " $\mathrm{K}$ " for $O$. niloticus of BSC slightly decreased on going from winter towards summer and related that to spawning. 
The sex ratio varies between different species of fishes (Khallaf and Authman, 2010). The overall sex ratio (M: F) of O. niloticus samples in the present study is (1:0.53, respectively). There is an obvious deviation from the expected (1:1) ratio. In African waters, males of cichlid populations are outnumbered than females (Fryer and Iles, 1972). This can be explained by the fact that females hide under plants during egg incubation so males are more susceptible to catch (Olele, 2010) or by the effect of high temperature on skewing sex towards male (El-sayed et al., 1996; Phelps and Popma, 2000; Devlin and Nagahama, 2002; Ahmed et al., 2007; Nivelle et al., 2019). It was reported that since 2015, unprecedented higher temperature was noticed due to global warming.

Gonadosomatic index is used to determine the maturity stages of gonad (Khallaf and Alne-na-ei, 1987; Vitale et al., 2006; McPherson et al., 2011; Flores et al., 2015). It increases with the maturation of fish then declines abruptly afterwards with spawning (Parameswarn et al., 1974). The GSI values of males in this study ranged between 0.13 to 1 , with corresponding standard lengths between $11-24 \mathrm{~cm}$. The matured males had the highest standard length of $23-24 \mathrm{~cm}$, indicating a direct relationship of the two parameters with $r^{2}$ equals to 0.92 . Females GSI values ranged between 0.29 to 1.42 , with corresponding standard lengths of 11-18 cm. The matured females had a standard length of 13-14 cm then maturity decreased with larger females. When age is considered, males GSI values ranged between 0.22 to 0.58 at the different lengths of the fish, while GSI values of females ranged between 1.11 to 1.34 . These results indicate that sexual maturity is achieved at smaller length and younger ages for females compared to males. This agrees with Shalloof and Salama (2008) who found that at the first sexual maturity $\left(\mathrm{L}_{50}\right)$ the body length of females $O$. niloticus was smaller than males, 10.5 and $11.5 \mathrm{~cm}$, respectively. Similarly, Hailu (2014) found that the sizes at first sexual maturity were $21.5 \mathrm{~cm} \mathrm{Tl}$ and $18.9 \mathrm{~cm} \mathrm{Tl}$, respectively, for male and female O. niloticus in Amerti, Ethiopia.

The monthly GSI values ranged between 0.09 to 0.71 for males and peaked in February, June, and August, respectively in descending order. Monthly GSI values of females ranged between 0.71 to 2.83 and peaked in March, May, and September, respectively in descending order. Consequently, spawning of O. niloticus, in this study, is predicted to extend from February to September. Khallaf et al. (2016b) reported similar results, since GSI of $O$. niloticus of BSC peaked in February, April, and September. The seasonal GSI for males ranged between 0.18 to 0.34 and peaked in winter and summer, while GSI of females ranged between 0.98 to 1.93 and peaked in spring only, this may explain the low condition of females in spring. These results indicate that $O$. niloticus in BSC is a multiple spawner (Khallaf et al., 1986). In general, GSI values of females at a given length, age, season, and month are higher than GSI values of males. This agrees with Teferi et al. (2001) for the same species but in Lake Chamo, Ethiopia. 
Of the 124 female samples, the values of fecundity ranged between 156-1224 with corresponding standard lengths between 11-18 cm and ranged between 733-1227, with corresponding weights between 60-21715g. The most fecund female had the highest length and weight of $18 \mathrm{~cm}$ and1217 $\mathrm{g}$, respectively, indicating the direct proportion of fecundity with length and weight of fish, which had a high $r^{2}$ values equal to 0.93 and 0.92 , respectively. These direct proportions of fecundity with length and weight of fish were proved through many studies on O. niloticus (Tadesse, 1997; Teferi et al., 2001; Shoko et al., 2015; Teame et al., 2018). And on other fish species (Rheman et al., 2002; Rahman et al., 2016; Olusegun et al., 2019). Absolute fecundity often has a direct proportion with the size and age of the fish (Bromage et al., 1992; Adamek et al., 2004).

Fecundity ranged between 537-686 with corresponding age groups1-5 years, in a direct proportion. The most fecund females were 5 years old. The age group 4 has expressed a slight decrease in value of fecundity, this may be attributed to the surrounding ecological factors, as the k value of female at age group 4 was not the best. Fecundity is not constant but varies with different environmental conditions and factors unique to species (Shafi, 2012). This fecundity-Age direct proportion strongly agree with the results obtained by Tahoun et al. (2008) which studied the effect of age on spawning performance of $O$. niloticus and found that the 3-years old female broodstock had a higher absolute fecundity than 1-years old female tilapia broodstock. The present results also agree with the findings of Getinet (2008) which studied the effects of maternal age $(4,9,16$, and 24 mo.) on fecundity, spawning interval, and egg quality of $O$. niloticus and found that overall age of females directly correlated with eggs per spawn (fecundity). In contrast, the results obtained by Valentin et al. (2015), which studied the maternal age (8 mo., 3 and 6 years) influences on reproductive rates of $O$. niloticus, indicated that there was no difference observed in the absolute fecundity between the different maternal age groups. This difference in results could be due to different location, handling managements, and feeding. However, in their work, comparable ages were used, but Tahoun et al. (2008) and Getinet (2008) study younger fishes. Therefore, the effects of age difference between studies on the obtained results cannot be ignored.

Monthly fecundity ranged between 359-1198 and peaked in February, May, October, and January, respectively in descending order. Seasonal fecundity of females ranged between 646-742 and has expressed a gradual decrease on going from winter to autumn. As the GSI value of female was the highest during spring (GSI =1.93), thus females spawned during spring season although the gonads were full with mature eggs in the winter, as the fecundity had the highest value $(\mathrm{F}=742)$, but in a pre-ripe phase waiting for the suitable warming in spring to ensure food availability for their subsequent fries.

Fecundity of $O$. niloticus was 687, 436, and 571, respectively, in the three months of summer (June, July, and August), where average temperature equaled 33.5, 35, and 35.5, respectively. This may be because the fecundity decreases with the excessively high 
temperatures as the amount of dissolved oxygen decreases and affects all biological processes of the fish such as egg formation. According to NASA (The US National Atmospheric and Space Administration), the summer of the years 2013 to 2018 is the highest temperature of the recorded weather history. The most efficient productive period of $O$. niloticus coincided with rising water temperature from 22 to $27^{\circ} \mathrm{C}$, as reported by El-Naggar et al. (2000), while studying effect of photoperiod, dietary protein and temperature on reproduction of $O$. niloticus. Hossan et al. (2013) revealed that egg production decreased with increased water temperature, the maximum eggs (1342 \pm 10.54$)$ were found at $32^{\circ} \mathrm{C}$ and no egg was found when the temperature was equal to or higher than $35^{\circ} \mathrm{C}$, while studying the effect of temperature and size variation on the egg and fry production by reared female Nile tilapia (Mymensingh: Bangladesh).The increase in value of fecundity in August with the high temperature of $35.5^{\circ} \mathrm{C}$ might be attributed to the difference in number of samples. As shown in fig. 22, there is a powerful association $\left(r^{2}=0.973\right)$ between fecundity and temperature. The mathematical representation could be equated to predict the maximum temperature that causes the lowest fecundity. This was found to be $38.75^{\circ} \mathrm{C}$, where fecundity would only be 180 eggs.

Another verification of such association is noticed in annual fecundity of $O$. niloticus in BSC, which ranged between 525 to 637 starting from 2014 till 2019. Fecundity varies with different environmental conditions and factors related to species itself (Shafi, 2012). Temperature and photoperiod are of the major affecting factors (Khallaf and Alne-na-ei, 1987; El-Naggar et al., 2000).

In concomitance, the Intergovernmental Panel on Climate Change (IPCC, 2001) predicted that global temperatures are likely to be increased by 1.4 to $6.4^{\circ} \mathrm{C}$ in this century. The summer of the years 2013 to 2018 is the highest temperature of the recorded weather history, according to NASA.

\section{REFERENCES}

Adamek, Z.; Andreji, J. and Henshaw, A. (2004): Stripping fecundity of common bream (Abramis brama L.) from the rivers Trent and Sow. Aquac. Int., 12:133-137.

Ahmed, A.A.; Abdallaa, M.S. and George, T.T. (2007): Egg Enumeration, incubation, hatching and development of the "Miracle Fish", Oreochromis niloticus, in the Sudan. AAC Special Publication, 12: 60-64.

Al-Zahaby, A.S.; El-Agamy, A.E.; El-Serafy, S.S. and Badawy, E.A. (1987): Preliminary observation on the relative growth and production of Tilapia species cultured in cages at three stocking densities. Qatar Univ. Sci. Bull., 7: 343-361.

Azevedo, P.A.; Cho, C.Y.; Leeson, S. and Bureau, D.P. (1998): Effects of feeding level and water temperature on growth, nutrient and energy utilization and waste outputs of rainbow trout (Oncorhynchus mykiss). Aquat. Living Resour., 11(4): 227-238. 
Bagenal, T.B. (1978): Aspect of fish fecundity. In: Gerking, S.D.(Ed.), The Ecology of Freshwater Fish Production. Blackwell Scientific Publications, Oxford, UK, pp. 75-101.

Barnham, C.A.; Baxter, A.F. and Victoria. (2003): Condition factor, K, for Salmonid fish. Melbourne: Dept. of Primary Industries.

Britz, P.J.; Hecht, T. and Mangold, S. (1997): Effect of temperature on growth, feed consumption and nutritional indices of Haliotis midae fed a formulated diet. Aquaculture, 152: 191-203.

Bromage, N.; Jones, J.; Randall, C.; Thrush, M.; Davies, B.; Sprinaget, J.; Duston, J. and Barker, G. (1992): Broodstock management, fecundity, egg quality and the timing of egg production in the rainbow trout (Oncorhynchus mykiss). Aquaculture, 100:141-166.

Chilton, D.E. and Beamish, R.J. (1982): Age determination methods for fishes studied by the Ground fish program at pacific Biological Station. Can. Spec. Publ. Fish. Aquat. Sci., 60: 102.

Devlin, R.H. and Nagahama, Y. (2002): Sex determination and sex differentiation in fish: An overview of genetic, physiological and environmental influences. Aquaculture, 208: 191-364.

El-Naggar, G.O.; El-Nady, M.A.; Kamar, M.G. and Al-Kholy, A.I. (2000): Effect of photoperiod, dietary protein and temperature on reproduction in Nile Tilapia, Oreochromis niloticus. 5thInternational symposium for tilapia aquaculture (ISTA) September 3-7, Barzil, p. 352.

El-Sayed, A.F.M.; El-Ghobashy, A. and Al-Amoudi, M. (1996): Effects of pond depth and water temperature on the growth, mortality and body composition of Nile tilapia, Oreochromis niloticus (L.). Aquac. Res., 27: 681-687.

FAO (2020): Cultured aquatic species information Program. Oreochromis niloticus. Cultured aquatic species information programme. text by Rakocy, J.E. in: FAO Fisheries and Aquaculture Department [online]. Rome. updated 18 February 2005. [cited 25 January 2020].

Flores, A.; Wiff, R. and Diáz, E. (2015): Using the gonadosomatic index to estimate the maturity ogive: application to Chilean hake (Merluccius gayi gayi). ICES Journal of Marine Science, 72(2): 508-514.

Fryer, G. and Iles, T.D. (1972): The cichlid fishes of the Great Lakes of Africa. Their biology and evolution. Oliver and Boyd, Edinburgh, 641 pp.

Gallardo-Cabello, M.E.; Espino-Barr, E.; Garcia-Boa, E.G.; Cabral- Solis, E.G. and PuenteGomez, M. (2007): Study of the growth of the green jack (Caranx caballus, Günther, 1868), in the Coast of Colima, Mexico. J. Fish. Aquat. Sci., 2(2): 131-139.

Getinet, G.T. (2008): Effects of maternal age on fecundity, spawning interval, and egg quality of Nile tilapia, Oreochromis niloticus (L.). J. World Aquacult. Soc., 39:671-677. 
Goncalves, J.M.S.; Bentes, L.; Lino, P.G.; Ribeiro, J.; Canario, A.V.M. and Erzini, K. (1997): Weight-length relationships for selected fish species of the small-scale Demersal Fisheries of the South and Southwest Coast of Portugal. Fish. Res., 30(3): 253-256.

Hailu, M. (2014): Gillnet selectivity and length at maturity of Nile tilapia (Oreochromis niloticus L.) in a tropical reservoir (Amerti: Ethiopia). J. Agr. Sci. Tech. A, 4: 135-140.

Hossan, S.; Ulka, S.B.; Motin, A.; Tarafder, A.; Sukhan, Z.P. and Rashid, H. (2013): Egg and fry production performance of female tilapia related to fluctuating temperature and size variation. 4th International conference on environmental aspects of Bangladesh, At Fukuoka, Japan.

https://www.accuweather.com/ar/eg/cairo/127164/weather-forecast

IPCC (2001): Climate Change 2001: The Scientific Basis. Contribution of Working Group I to the Third Assessment Report of the Intergovernmental Panel on Climate Change [Houghton, J.T.; Ding, Y.; Griggs, D.J.; Noguer, M.; van der Linden, P.J.; Dai, X.; Maskell, K.and Johnson , C.A. (Eds.)], Cambridge University Press, Cambridge, United Kingdom and New York, USA, 881pp.

Ishak, M.M.; Al-Sayes, A.A and Talaat, K.M. (1985): Tilapia fisheries in Lake Borollus, Egypt. Kuwait Bull. Sci. Res., 6: 225-242.

James, P.S.B.R.; Chendrasekhar Gupta, T.R. and Shanbhogue, S.L. (1978): Some aspects of the biology of ribbon fish, Trichiurus lepturus (Linnaeus). J. Mar. Biol., 290:120-137.

Khallaf, E.A.; Latif, A.F.A. and Alne-na-ei, A.A. (1986): Reproduction of Tilapia nilotica and T. zillii in a Nile canal and its interaction with the environment. Delta J. Sci., 10(2): 724-747.

Khallaf, E.A. and Alne-na-ei, A.A. (1987): Feeding ecology of Oreochromis niloticus (Linnaeus) \& Tilapia zillii in a Nile Canal. Hydrobiologia, 146: 57-62.

Khallaf, E.A. and Authman, M. (1991): Growth and mortality of Bagrus bayad (Forskal) in Bahr Shebeen Nilotic Canal. J. Egypt. Ger. Soc. Zool., 4: 87-109.

Khallaf, E.A. (1992): Evaluation of the fisheries of Oreochromis niloticus at Bahr Shebeen Canal- Nile Delta, Egypt. J. Egypt. Ger. Soc. Zool., 7 B: 27-44.

Khallaf, E.A. and Authman, M.N. (1992): Changes in diet, prey size and feeding habit in Bagrus bayad, and possible interactions with B. docmac in a Nile Canal. Environ. Biol. Fish., 34(4): 425-431.

Khallaf, E.A; Galal, M. and Athuman, M. (2003): The biology of Oreochromis niloticus in a Polluted Canal. Ecotoxicology, 12(5): 405-416.

Khallaf, E.A.H. and Athuman, M.M.N. (2010): Some biological aspects of the Nile mormyrid fish (Mormyrus kannume, Forsskål, 1775), from Bahr Shebeen Nilotic canal, Egypt. World J. Fish Mar. Sci., 2(5): 357-375. 
Khallaf, E.A.; Alnenaei, A.A. and Elgindy, R.M. (2016a): Fish Biology and Fishery of Oreochromis niloticus in Bahr Shebeen Canal, Delta of Egypt. Egypt. J. Aquat. Biol. \& Fish., 20(4): 83-88.

Khallaf, E.A.; Galal, M.; Authman, M.M.N. and Zaid, R.A. (2016b): A Comparative Study on the Water Quality of Two Nilotic Canals in the Delta of Egypt. J. Aquac. Res. Development, 7:12. doi: 10.4172/2155-9546.1000462

Khallaf, E.A.; Alne-na-ei, A.A.; El-Garawani, I.M. and Elgendy, R.G. (2019): A study on growth, mortality and a biochemical growth indicator of Oreochromis niloticus in a Nile Canal, Egypt. Egyptian Journal of Aquatic Biology \& Fisheries, 23(2): 639- 656.

Lagler, K.F. (1956): Freshwater Fishery Biology. W.M.C. Brown Co. Dubuque, Iowa, USA, 421pp.

Latif, A.F.A. and Khallaf, E.A. (1987): Growth and mortality of Tilapia species in Lake Nasser. Sc. J. of Fac. Sci., Almenoufia Univ., Shebeen Alkoom, Egypt, 1(1): 34-53.

Le Cren, E.D. (1951): The length-weight relationship and seasonal cycle in gonad weight and condition in the perch (Perca fluviatilis). J. Anim. Ecol., 20(2): 201-219.

McPherson, L.R.; Ganias, K. and Marshall, C.T. (2011): Inaccuracies in routinely collected Atlantic herring (Clupea harengus) maturity data and correction using a gonadosomatic index model. J. Mar. Biolog. Assoc. U. K., 91: 1477-1487.

McQuinn, I.H. (1989): Identification of spring- and autumn-spawning herring (Clupea harengus harengus) using maturity stages assigned from gonadosomatic index model. Can. J. Fish. Aquat. Sci., 46: 969-980.

Mohammed, E.Y. and Uraguchi, Z.B. (2013): Impacts of climate change on fisheries, implications for food security in Sub-Saharan Africa. In: Global Food Security. Hanjra, M.A. (Ed.), Nova Science Publishers, Inc., 114-135.

Murua, H.; Kraus, G.; Saborido-Rey, F.; Witthames, P.R.; Thorsen, A. and Junquera, S. (2003): Procedures to estimate fecundity of marine fish species in relation to their reproductive strategy. J. Northwest Atl. Fish. Sci., 33: 33-54.

Nivelle, R.; Gennotte, V.; Kalala, E.J.K.; Ngoc, N.B.; Muller, M.; Mélard, C. (2019): Temperature preference of Nile tilapia (Oreochromis niloticus) juveniles induces spontaneous sex reversal. PLoS ONE, 14(2): e0212504.

Olele, N.F. (2010): Reproductive biology of Sarotherodon galilaeus (Artedi, 1757) in Onah Lake, Delta state, Nigeria, J. Applied Sci. Res., 6: 1981-1987.

Olurin, K.B. and Aderibigbe, O.A. (2006): Length-Weight Relationship and Condition Factor of Pond Reared Juvenile Oreochromis niloticus. World Journal of Zoology, 1(2): 82-85. 
Olusegun, A.E.; Idowu, A.F.; Oghenebrorhie, O.M.T. (2019): Assessment of fecundity of Brycinus macrolepidotus in Akomoje water reservoir, Abeokuta, South West, Nigeria. Egyptian Journal of Aquatic Biology \& Fisheries, 23(1): 245-252.

Özaydin, O.; Uckun, D.; Akalın, S.; Leblebici, S. and Tosunoglu, Z. (2007): Length-weight relationships of fishes captured from Izmir Bay, Central Aegean Sea. J. Appl. Ichthyol., 23(6): 695-696.

Parameswarn, S.; Sevaraj, C. and Radhakrisshnan, S. (1974): Observation on the biology of Labeo gonius (Hamilton). Indian J. fish., 21: 54-75.

Phelps, R.P. and Popma, T.J. (2000): Sex reversal of tilapia. In: Costa-Pierce, B.A. and Rakocy, J.E. (Eds.), Tilapia Aquaculture in the Americas, The World Aquaculture Society, Baton Rouge, LA, United States, 2: 34-59.

Pope, K.L. and Willis, D.W. (1996): Seasonal influences on freshwater fisheries sampling data. Reviews in Fisheries Science, 4(1): 57-73.

Rahman, M.; Hossain, Y.; Parvin, S.; Rahman, S.; Ahmed, Z.F.; Ohtomi, J. and Abd Allah, E.F. (2016): Fecundity of the threatened fish, Mystus vittatus (Siluriformes: Bagridae) in the Padma River, Bangladesh. Sains Malays., 45(6): 899-907.

Rheman, S.; Islam, M.L.; Shah, M.M.R.; Mondal, S. and Alam, M.J. (2002): Observation on the fecundity and gonadosomatic index (GSI) of Grey Mullet Liza parsia (Ham.). Online J. Biol. Sci., 2(10): 690-693.

Ricker, W.E. (1975): Computation and interpretation of biological statistics of fish populations. Bull. Fish. Res. Board Can., 191: 1-382.

Rounsefell, G.A. and Everhart, W.H. (1953): Fishery science: Its methods and applications. John Wiley \& Sons, NY.

Sarkar, U.K.; Khan, G.E.; Dabas, A.; Pathak, A.K.; Mir, J.I.; Rebello, S.C.; Pal, A. and Singh, S.P. (2013): Length-weight relationship and condition factor of selected fresh water fish species found in River Ganga, Gomti and Rapti, India. J. Environ. Biol., 34(5): 951-956.

Shafi, S. (2012): Study on fecundity and GSI of Carassius carassius (Linneaus, 1758) introduced from Dal Lake, Kashmir. Journal of Biology, Agriculture and Healthcare, 2(3): 68-75.

Shalloof, K.A.S and Salama, H.M.M. (2008): Investigations on some aspects of reproductive biology in Oreochromis niloticus (Linnaeus, 1757) inhabited Abu-zabal Lake, Egypt. Glob. Vet., 2(6): 351-359.

Shoko, A.P.; Limbu, S.M.; Mrosso, H.D.J. and Mgaya, Y.D. (2015): Reproductive biology of female Nile tilapia Oreochromis niloticus (Linnaeus) reared in monoculture and polyculture with African sharptooth catfish Clarias gariepinus (Burchell). SpringerPlus, 4:275. 
Tadesse, Z. (1997): Breeding season, fecundity, length-weight relationship and condition factor of Oreochromis niloticus L. (Pisces: Cichlidae) in Lake Tana, Ethiopia. Ethiop. J. Sci., 20(1): 3147.

Tahoun, A.M.; Ibrahim, M. A-R.; Hammouda, Y.F.; Eid, M.S.; Zaki El-Din, M.M.A. and Magouz, F.I. (2008): Effects of age and stocking density on spawning performance of Nile tilapia, Oreochromis niloticus (L.) broodstock reared in hapas. In: 8thInternational Symposium on Tilapia in Aquaculture, Cairo, pp. 329-344.

Teame, T.; Zebib, H. and Meresa, T. (2018): Observations on the biology of Nile tilapia, Oreochromis niloticus L., in Tekeze Reservoir, Northern Ethiopia. Int. J. Fish. Aquac., 10(7): 86-94.

Teferi, Y; Admassu, D. and Mengistou, S. (2001): Breeding season, maturation and fecundity of Oreochromis niloticus L. (Pisces: Cichlidae) in Lake Chamo, Ethiopia. Ethiop. J. Sci., 24(2): 255-264.

Tsadik, G.G. and Bart, A.N. (2007): Effect of feeding, stocking density and water-flow rate on fecundity, spawning frequency and egg quality of Nile tilapia, Oreochromis niloticus (L.). Aquaculture, 272: 380-388.

Valentin, F.N.; Do Nascimento, N.F.; Da Silva, R.C.; Tsuji, E.A.; Paes, M.D.F.; Koberstein, T.C.R.D. and Nakaghi, L.S.O. (2015): Maternal age influences on reproductive rates in Nile tilapia (Oreochromis niloticus). R. Bras. Zootec., 44(4): 161-163.

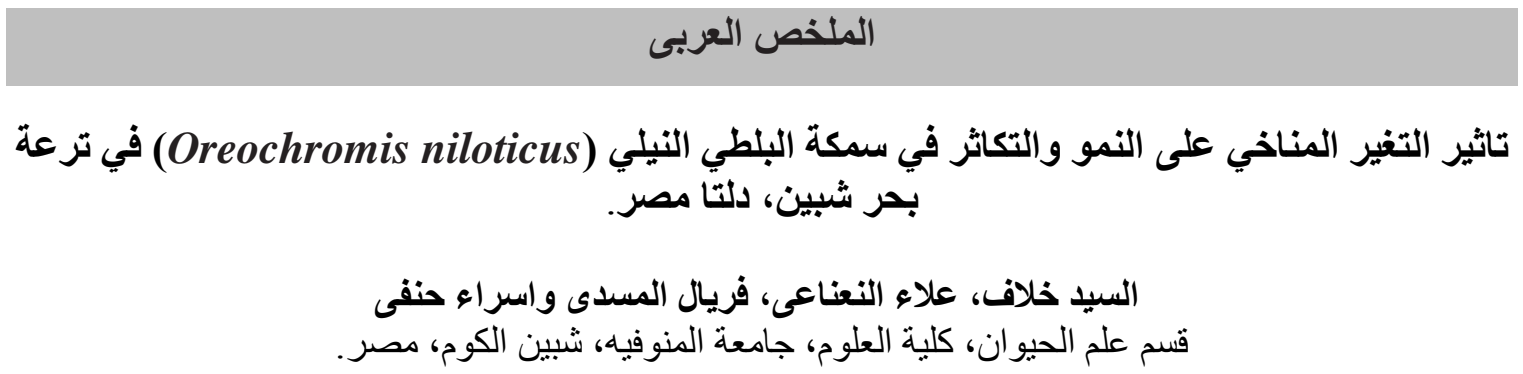

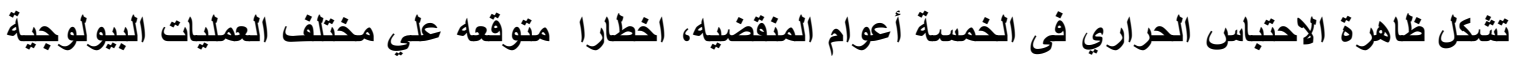

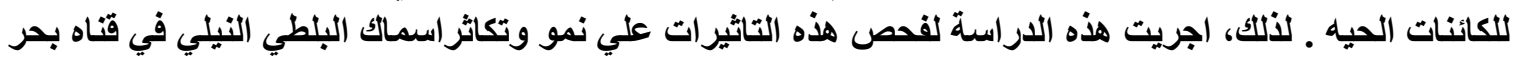
شبين فى دلتا مصر.

وقد اظهرت الدراسه أن النمو الطولي للاسماك حقى دلالات احصائية عالية، حيث حقى معامل الارتباط قيم مساوية

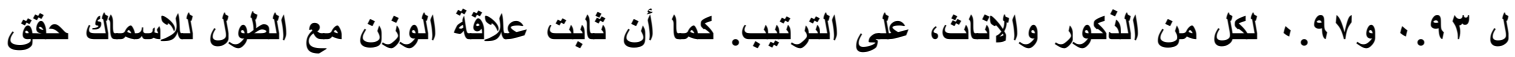

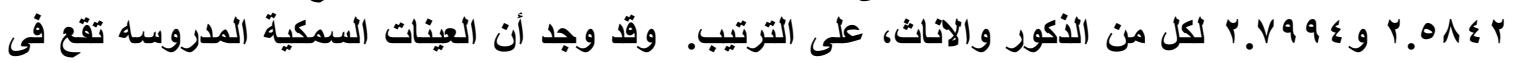

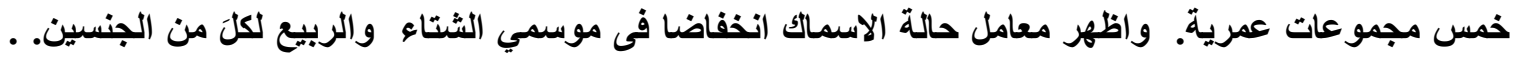

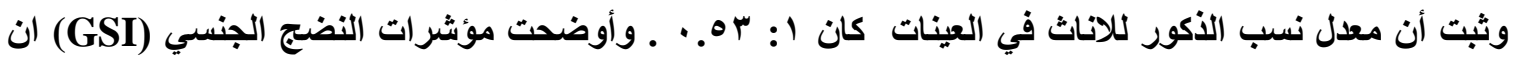




مناقثتها ومقارنتها بالدراسات السابقة ، وثبث ربطهاء بالارتفاع الحادث في درجات الحرارة. 